\title{
Characterising flow regime and interrelation between surface-water and ground-water in the Fuente de Piedra salt lake basin by means of stable isotopes, hydrogeochemical and hydraulic data
}

\author{
Claus Kohfahl ${ }^{\mathrm{a}, *}$, Miguel Rodriguez ${ }^{\mathrm{b}}$, Cord Fenk ${ }^{\mathrm{a}}$, Christian Menz ${ }^{\mathrm{a}}$, \\ Jose Benavente ${ }^{c}$, Hans Hubberten ${ }^{d}$, Hanno Meyer ${ }^{d}$, Liisa Paul ${ }^{a}$, \\ Andrea Knappe ${ }^{a}$, Juan Antonio López-Geta ${ }^{e}$, Asaf Pekdeger ${ }^{a}$ \\ ${ }^{a}$ Freie Universität Berlin, Institute of Geological Sciences, Malteserstr. 74-100, D-12249 Berlin, Germany \\ b Universidad Pablo de Olavide, Department of Physical, Chemical and Natural Systems, Utrera Road, km 1, \\ 41013 Sevilla, Spain \\ c Universidad de Granada, Water Research Institute, Ramón y Cajal Street No. 4, 18071 Granada, Spain \\ ' Alfred Wegener Institute, Telegrafenberg A43, D-14473 Potsdam, Germany \\ e Instituto Geológico y Minero de España, Ríos Rosas 23, 28003 Madrid, Spain
}

Received 12 March 2007; received in revised form 6 December 2007; accepted 7 December 2007

\section{KEYWORDS}

Salt lake;

Stable isotopes of water; Hydrogeochemistry; Geochemical modelling; Inverse geochemical modelling

\begin{abstract}
Summary This research reports the characterisation of ground- and surface-water interaction in the Fuente de Piedra Salt lake basin in southern Spain by a combined approach using hydraulic, hydrogeochemical and stable isotope data. During three sampling campaigns (February 2004, 2005 and October 2005) ground- and surface-water samples were collected for stable isotope studies $\left({ }^{18} \mathrm{O}, \mathrm{D}\right)$ and for major and minor ion analysis. Hydraulic measurements at multilevel piezometers were carried out at four different locations around the lake edge. Conductivity logs were performed at four piezometers located along a profile at the northern lake border and at two deeper piezometers in the Miocene basin at a greater distance from the lake. To describe processes that control the brine evolution different hydrogeochemical simulations were performed. Hydrogeochemical data show a variety of brines related to thickness variations of lacustrine evaporites around the lake. Salinity profiles in combination with stable isotope and hydraulic data indicate the existence of convection cells and recycled brines. Furthermore restricted
\end{abstract}

\footnotetext{
* Corresponding author. Tel.: +49 30838 70472; fax: +49 3083870742 .

E-mail address: kohfahl@zedat.fu-berlin.de (C. Kohfahl).
} 
ground-water inflow into the lake was detected. Dedolomitisation processes were identified by hydrogeochemical simulations and different brine origins were reproduced by inverse modelling approaches.

(c) 2007 Elsevier B.V. All rights reserved.

\section{Introduction}

Salt lakes occur in arid to semi-arid environments whenever internally drained basins are formed due to tectonic activity or dissolution processes and the floors of such basins intersect the water-table (Duffy and Al-Hassan, 1988; Yechieli and Wood, 2002). The main requirement for the occurrence of a saline lake is that evaporation exceeds precipitation (Hardie et al., 1978).

Salt lakes give insights in sedimentary history and palaeoclimate. They often provide economically valuable evaporate minerals and they are important for water resources assessments because they may affect the ground-water quality in their vicinity (Yechieli and Wood, 2002).

Topographically, these environments range from essentially planar surfaces like the sabkhas of the Arabian Gulf through closed, shallow basins with seasonal standing water like Fuente de Piedra salt lake or the salt lakes of Western Texas, to well-developed, closed basins containing permanent water bodies such as the Dead sea or Great salt lake (Yechieli and Wood, 2002).

With regard to the hydrogeologic background, a distinction is made between coastal sabkhas and inland sabkhas (playas, saline lakes, salt lakes). These inland saline systems are subdivided according to the elevation of the land surface in relation to the ground-water-table. A discharge playa occurs when the level of the capillary fringe is in coincident with the playa floor, which is the case in the Fuente de Piedra salt lake. Extensive accumulation of evaporates usually occurs in these environments. Discharge playas that are subjected to continuous subsidence at rates that exceed the rate of sediment accumulation may evolve into saline lakes like the Dead Sea which are permanently inundated (Rosen, 1994).

Because evaporation concentrates the salt lake water, the brine, driven by density forces may flow into the fresher ground-water. As long as brine is supplied, cellular flow circulation may occur below the salt lake bottom until it reaches the impermeable substratum. This scenario is known as "free convective flow" (Fan et al., 1997). Free convective flow is very slow and could be considered negligible for the calculation of a water budget at a given salt lake environment.

A large number of modelling approaches regarding density driven flow have been performed to characterise the ground-water flow below and in the vicinity of salt lakes and playas. Most of these codes include density driven flow and are applied for prognostic issues focusing on salinisation in different watershed scenarios. Rogers and Dreiss (1995) simulated the basin-wide saline ground-water distribution in Mono basin, California. Other investigations were carried out in the Murray-Darling basin where more than 200 saline water disposal basins are impacting the underlying aquifers and the river Murray (Narayan and Armstrong, 1995; Simmons et al., 2002). Further modelling studies focused on density-dependent ground-water hydrodynamics beneath saline disposal basins and the development of convection cells (Fan et al., 1997; Simmons and Narayan, 1997; Simmons et al., 1999; Wooding et al., 1997a; Wooding et al., 1997b). Using laboratory experiments and numerical modelling, Johannsen et al. (2006) investigated fingering instabilities of brines underlain by freshwater.

Besides these transport modelling studies, a number of field studies were performed to characterise ground-water flow and brine evolution in saline environments using stable isotope data. Among the environmental tracers that have proved useful in many hydrogeological investigations due to their abundance and the simplicity of their analytical determination are stable isotopes of ${ }^{18} \mathrm{O}$ and $\mathrm{D}$ (Aketwana and Richardson, 2004; Craig and Gordon, 1965; Gonfiantini, 1986; Vallejos et al., 1997; Zimmermann, 1979). As they constitute a part of the $\mathrm{H}_{2} \mathrm{O}$ molecule, they are natural tracers behaving chemically like water. An important factor for studies of closed lakes is isotopic alteration by rapid evaporation. This process leads to a kinetic fractionation of oxygen and causes the water to shift to the right of the meteoric ${ }^{18} \mathrm{O}-\mathrm{D}$ water line. Water subjected to rapid evaporation evolves along an evaporative line, with a slope less than eight. The slope depends on local climatic conditions, particularly the humidity in the air (Clark and Fritz, 1999). When surface-water that has been subjected to evaporation infiltrates into the ground-water it can be easily identified by its isotopic fingerprint and provides a helpful means to characterise the flow regime.

Mineral precipitation and brine evolution for a chemically controlled closed system are determined by the chemical divide concept (Hardie and Eugster, 1970). If water evaporates and leads to mineral precipitation, the concentrations remain fixed if the concentration ratios in solution are equal to the stoichiometric ratios in the mineral. However, if the ratios are different, the solute with the highest concentration increases, while all the other constituents of the mineral decrease in concentration as soon as the mineral starts to precipitate. This process may lead to a variety of brine compositions depending on the initial ion ratios. Wood and Sanford (1990) modified this chemical divide concept for the more common open hydrological system. Further important factors that control the hydrogeochemical evolution of brines are dissolution and precipitation processes such as dolomitisation and dedolomitisation (Yechieli and Wood, 2002).

Hydrogeochemical simulations have to account for the activities of the different solutes. For concentrated brines it is generally agreed that the Pitzer equations (Pitzer, 1987) currently provide the most satisfactory method of calculating activities. An example for their application is published by Liu et al. (2004) who performed hydrogeochemical simulations to characterise the geochemical evolution of brines and salt minerals. 
Salt lake systems with large variations in chemical and stable isotopic composition and complex flow systems are not yet well understood. In this work, hydrogeochemical and stable isotope information combined with hydrogeochemical modelling is used to supplement hydraulic field data to delineate the ground-water flow patterns and brine evolution around the Fuente de Piedra salt lake. Hydrogeochemical modelling approaches regarding brine evolution have also been poorly addressed in the literature. The objectives of this paper are to (1) combine chemical and stable isotope data with hydraulic data to constrain ground-water flow and interaction of surface-water and ground-water, (2) identify the main processes that control the hydrogeochemical composition of different brines, (3) determine the factors that lead to the wide range of salinity observed in the surface and subsurface-water system.

\section{Study area}

The Fuente de Piedra salt lake is located in the Antequera region of southern Spain (Fig. 1). The lake occupies the centre of a topographically closed basin in the Antequera region with a watershed area of about $150 \mathrm{~km}^{2}$. The Fuente de Piedra salt lake is $6.8 \mathrm{~km}$ long and $2.5 \mathrm{~km}$ wide.

The study site forms part of a protected wetland at regional (natural reserve), European (special bird protection area) and international (Ramsar site) level. It is an ideal nesting area for the pink flamingo (Phoenicopterus ruber roseus) because of the shallow water depth that reaches an average value of $70.5 \mathrm{~cm}$ (Rodríguez-Rodríguez, 2002). For this reason the salt lake counts as one of the most important breeding places for this species in the western Mediterranean (Rendón, 1996).

The salt lake is located in an intramontane basin in the Betic Cordillera which evolved due to tectonic extension during the Neogene. Besides Fuente de Piedra several small endoreic basins exist within this area, which are all underlain by Triassic sediments composed mainly of clays, sandstones and evaporites (Linares and Rendón, 1999). These sediments are characterised by low hydraulic conductivities (Vera, 2004) and constitute the almost impervious basement leading to the formation of numerous closed basins hosting salt lakes throughout the Antequera region. Karstification due to the dissolution of Triassic evaporites is regarded as the governing process leading to the subsidence of these basins. Although the Triassic evaporites are reported to be mainly composed of gypsum (Cruz-SanJulián, 1974), Heredia et al. (2004) report saline springs with elevated proportions of sodium and chloride which are clearly related to dissolution of Triassic evaporites pointing to a more heterogeneous composition. These basins were filled up with late Miocene materials whereupon conditions changed from marine to continental.

Rocks outcropping in the drainage basin consist of tertiary marine sediments (bio-clastic sandstones) covered with Quaternary fluvial materials. The tertiary marine sediments are underlain by reddish-green Triassic marls and evaporites (Keuper) along with other types of rocks that can be locally affected by karstification (Fig. 2). Jurassic and Cretaceous materials constitute the mountain ranges

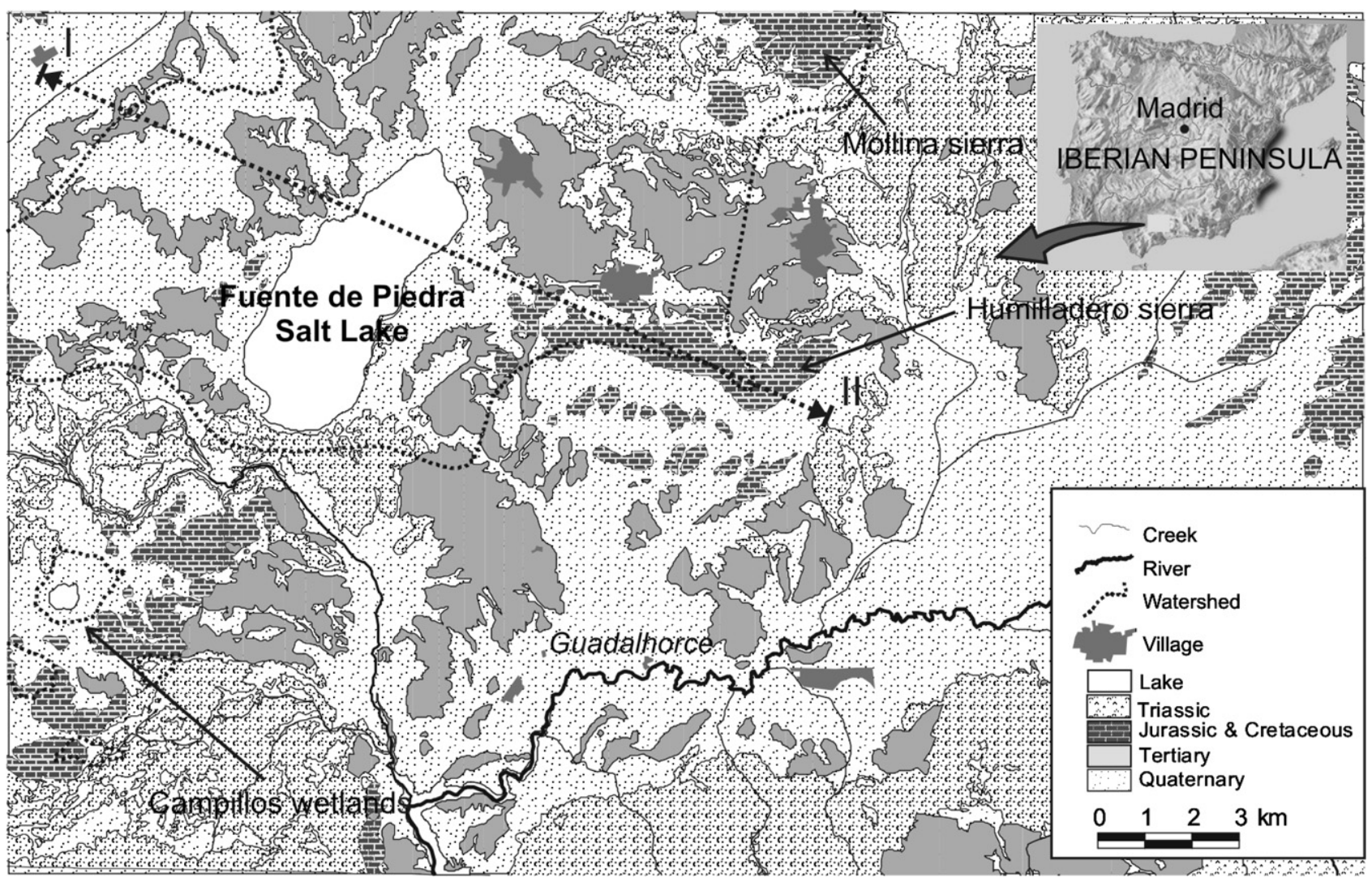

Figure 1 Regional geological map of study area and location of the geological profile A. Geology was simplified after ITGE (1998). 


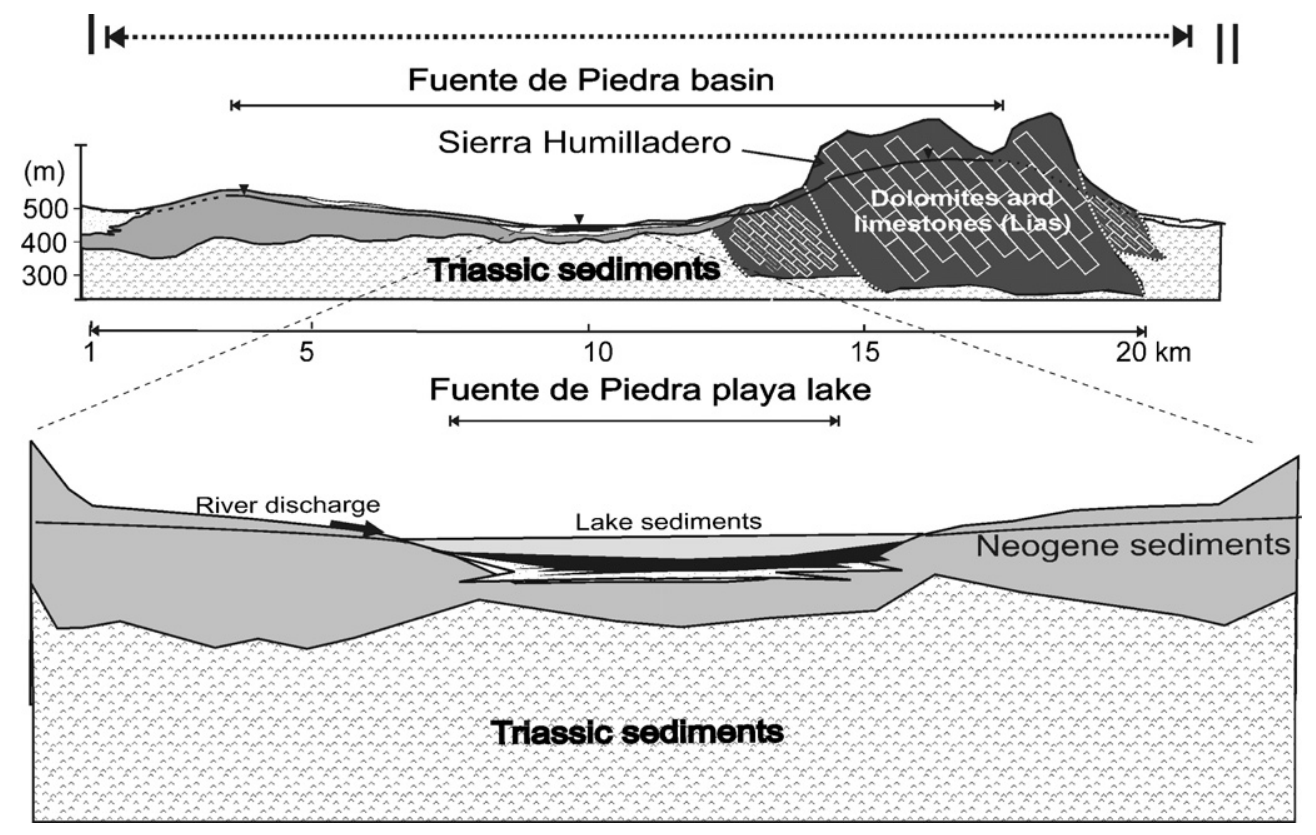

Figure 2 Schematic geological profile illustrating the principal units of the study area.

in the drainage basin. Detritic quaternary sediments are deposited below the lacustrine sediments in the central part of the Fuente de Piedra basin.

Bio-clastic sandstones and the mountain ranges, together with the uppermost quaternary alluvium, are important local ground-water reservoirs (ITGE, 1998). Since 1977 several drillings have been made in the basin by the geological survey of Spain (Instituto Geológico y Minero de España). The lithologic information obtained from the cores indicates that clayey materials are abundant near the salt lake and normally appear below a shallow detritic quaternary covering or outcrop directly. Only the tertiary marine sediments and the Jurassic and Cretaceous materials of the mountain ranges present considerable depths, ranging from $15 \mathrm{~m}$ to more that $100 \mathrm{~m}$. Since no drillings deeper than $3 \mathrm{~m}$ were carried out within the lake area, no hydrogeological information is available here.

Sampling of lacustrine sediments is described in (Rodríguez Jiménez et al., 1993) both the surface salt crust and in two shallow boreholes of $3 \mathrm{~m}$ depth close to the shoreline of the lake. Fifteen samples of each sediment core were taken at different depths. The upper salt crust of the sediment profiles had a thickness of about $2 \mathrm{~cm}$, underlain by a black layer of $20 \mathrm{~cm}$ enriched in organic matter. In the internal zone of the salt lake the upper salt crust shows a variety of minerals (halite, gypsum, mirabilite and polyhalite) whereas detritic materials become more important towards the edges. Below the organic layer, the sedimentary sequence is composed of more or less homogeneous gypsum clay interbedded with levels of autochthonous gypsum crystals. The sediment analyses yielded the mineral phases dolomite and calcite (40-50\%), phyllosilicates (20-30\%), gypsum (5-20\%), quartz and feldspars (20-30\%) and small amounts of halite and other minerals, i.e. a proportion of 40-60\% detritic sediments. Rodríguez Jiménez et al. (1993) detected a lateral zonation with increasing salt contents towards the centre of the lake as well as a vertical trend of dolomitisation and diagenetic growth of gypsum crystals. Additionally, minerals such as hexahydrite, bassanite, bischofite, illite and caolinite were identified below the organic layer.

Fuente de Piedra salt lake is a hyper saline lake of the $\mathrm{Cl}-\left(\mathrm{SO}_{4}\right)-\mathrm{Na}-(\mathrm{Mg})-(\mathrm{Ca})$-type. Documented concentrations of dissolved solids vary between $18 \mathrm{~g} / \mathrm{L}$ and $200 \mathrm{~g} / \mathrm{L}$ (Almécija, 1997; Moreira and Montes, 2005; Rodríguez-Rodríguez, 2002).

The hydrogeological boundaries of the Fuente de Piedra aquifer coincide with the superficial watershed divide (Linares, 1990). The average annual recharge and potential evapotranspiration are estimated at $460 \mathrm{~mm} / \mathrm{a}$ and $830 \mathrm{~mm} / \mathrm{a}$, respectively. The salt lake is fed by surface runoff from periodic and ephemeral rivers (Arroyo Santillán and Charcón), by ground-water inflow and by rainfall (ITGE, 1998; Linares, 1990). Recent results from the water budget in Fuente de Piedra salt lake (Heredia et al., 2004; Linares and Rendón, 1999; Rodríguez-Rodríguez et al., 2006a) show that total water input of $2 \times 10^{7} \mathrm{~m}^{3} / \mathrm{y}$ is expected to occur in the watershed. Nearby hypersaline springs show tritium ages younger than 50 years and low $\mathrm{Ca}$ and $\mathrm{Mg}$ concentrations (Heredia Díaz et al., 2004). Fuente de Piedra brines which according to Heredia et al., (2004) do not show tritium are not expected to discharge into these saline springs and therefore a closed system is assumed. The salt lake normally desiccates in summer: it only remains flooded throughout the whole year during abnormally wet periods, most recently in the summers of 1997 and 1998 (Rodríguez-Rodríguez et al., 2006a). According to Rosen (1994) the Fuente de Piedra lake can be classified as a discharge playa.

Tritium analysis carried out by Heredia et al. (2004) yielded high concentrations within the Miocene aquifer indicating ground-water ages younger than 50 years which points to comparatively fast ground-water flow at a greater distance from the lake. By contrast, brine samples taken 
from the lake sediments yielded tritium ages of more than 50 years and indicate longer residence times due to low hydraulic conductivities of lacustrine sediments.

Rodríguez-Rodríguez et al. (2006b) presented a numerical model to examine the effects of upward fluxes on the geometry of the salinity interface. They found that upward flux of ground-water from underlying formations is essential for the basin recharge.

Electric tomography profiles for the location and characterisation of the brines below and around the playa lake carried out by Ruiz et al. (2006) yielded elevated conductivities reflecting the presence of salt or saltwater up to a maximum depth of $100 \mathrm{~m}$ in the northern part below the centre of the lake. Towards the lake shore the vertical extension of elevated conductivities decreases significantly and is reduced to local lenses in the direct vicinity of the lake.

Recent mapping of the uppermost meters in the basin north of the lake shore indicates that the former lake extended about $3 \mathrm{~km}$ further north (Fenk and Menz, 2007).

\section{Methods}

To enable sampling at different depths and to characterise lacustrine sediments, five shallow boreholes of 4-7 m depth were drilled with a compressed air hammer beside preexisting piezometers during September/October 2005. A 2 in. HDPE piezometer was installed in each borehole.

During three sampling campaigns (February 2004, 2005, October 2005) ground- and surface-water samples were collected for stable isotope studies $\left({ }^{18} \mathrm{O}\right.$, D) for major $\left(\mathrm{Ca}^{2+}, \mathrm{Mg}^{2+}, \mathrm{Na}^{+}, \mathrm{K}^{+}, \mathrm{Cl}^{-}, \mathrm{SO}_{4}{ }^{2-}, \mathrm{NO}_{3}{ }^{-}, \mathrm{Br}^{-}\right)$and minor ion $\left(\mathrm{Fe}^{2+}, \mathrm{Mn}^{2+}, \mathrm{Sr}^{2+}\right)$ analysis. The entire sampling network is listed in Table 1 and Fig. 3 and includes 27 sampling locations. Surface-water could only be sampled during the winter months in February 2004 and 2005 and was taken in the laguna, the Santillán creek and the peripheral creek of the laguna.

The largest sampling campaign was carried out during September/October 2005. Here ground-water was sampled by pumping after constant values of conductivity and redox potential had been established. Measurements for $\mathrm{pH}$, temperature and conductivity were carried out in the field. Surface- and ground-water samples were filtered immediately after sample retrieval for analysis of cations and anions using $0.45 \mu \mathrm{m}$ membrane filters. Samples for cation analysis were preserved with concentrated nitric acid. In most cases alkalinity of filtered samples was determined in the field by titration with $\mathrm{HCl}(0.1 \mathrm{M})$, otherwise alkalinity samples were collected in glass bottles which were carefully filled without any air entrapment for analysis in the laboratory. Additional samples from piezometers were taken in February 2004 and February 2005 by a plastic ladle without pumping and without filtering. All collected samples were stored at $4{ }^{\circ} \mathrm{C}$ in polypropylene bottles $(50 \mathrm{ml})$ with watertight caps.

Major cation analysis of pore water was carried out on acidified samples using ICP-AES (Perkin-Elmer AAS 5000), whereas major anions were determined using ion chromatography (Dionex DX-100). Iron was analysed as total Fe.

The stable isotopes of water were analysed at the Alfred Wegener institute (AWI) in Potsdam using a Finnigan MAT
Delta-S mass spectrometer equipped with two equilibration units for the online determination of hydrogen and oxygen isotopic composition (Meyer, 2000). The concentrations are given hereafter in $\delta$-units calculated with respect to VSMOW (Vienna standard mean ocean water) expressed in permil.

$\delta(\%)=1000\left(\frac{R_{\text {Sample }}-R_{\mathrm{VSMOW}}}{R_{\mathrm{VSMOW}}}\right)$

where $R_{\text {sample }}$ and $R_{\mathrm{VSMOW}}$ are the isotopic ratios of the sample and of the VSMOW, respectively. The external errors of long-term standard measurements for hydrogen and oxygen are better than $0.8 \%$ and $0.10 \%$, respectively.

The isotope salt effect is defined as the ratio of the liquid-vapour equilibrium fractionation factor for pure water to that for the salt solution following Horita et al. (1995). A salt effect is well known for oxygen isotopes and may be corrected if the chemical composition of the aqueous solution is known (Bourg et al., 2001). Hydrogen isotopes also showed significant and reproducible fractionation. A preliminary correction factor for the isotope salt effect was determined for the equilibration method used at the AWI (Meyer, 2000). For a series of synthetic solutions of $\mathrm{NaCl}$ (provided by the FU Berlin and mixed with a water of known isotopic composition), the salt effect for both oxygen and hydrogen isotopic fractionation could be determined. The isotope salt effect is nearly linear and was corrected as follows:

$\delta^{18} \mathrm{O}_{\text {Corrected }}=\delta^{18} \mathrm{O}_{\text {measured }}-+(0.072 \times \mathrm{C}(\mathrm{NaCl})$ in $\mathrm{mol} / \mathrm{L})$

$\delta \mathrm{D}_{\text {Corrected }}=\delta \mathrm{D}_{\text {measured }}+(2.278 \times \mathrm{C}(\mathrm{NaCl})$ in $\mathrm{mol} / \mathrm{L})$

with $\mathrm{c}=$ concentration.

This is in good qualitative agreement with the corresponding slope values of $+0.06 \% / \mathrm{mol}$ and $+2.49 \% / \mathrm{mol}$ for monovalent salts presented by Bourg et al. (2001). The latter values were obtained with a gas-water equilibration method similar to the technique used in this study.

The hydrogeochemical model, PHREEQC-2, version 2.13.2 (Parkhurst and Appelo, 1999) was used to perform the hydrogeochemical simulations. The Davis equation used to calculate the strength of ion activities (I) in PHREEQC is not applicable for solutions with ionic strength greater than 0.5. Therefore, the PITZER database was used to calculate saturation indices for samples with an ionic strength higher than 0.5. The PITZER database was also applied for the inverse modelling and the simulation of evaporation.

\section{Results and discussion}

\section{Sediments}

The sediment cores of the five shallow boreholes yielded more or less homogeneous clayey lacustrine sediments overlain by an organic layer of a few centimeter and the salt crust at the top. Occasionally fine layers of a few centimeter thickness containing fine sand were identified and also levels with gypsum crystals were also observed. These findings concur with the results of Rodríguez Jiménez et al. (1993), who state that phyllosilicates, quartz and feldspars 
Table 1 Locations and characteristics of sampling network

\begin{tabular}{|c|c|c|c|c|c|c|c|c|}
\hline Site ID & Type & $\begin{array}{l}\text { Depth } \\
\text { below } \\
\text { surface }(\mathrm{m})\end{array}$ & $\begin{array}{l}\text { Diameter } \\
(\mathrm{m})\end{array}$ & $\begin{array}{l}\text { Top of screen } \\
\text { (in m below } \\
\text { surface) }\end{array}$ & $\begin{array}{l}\text { February } \\
2004\end{array}$ & $\begin{array}{l}\text { February } \\
2005\end{array}$ & $\begin{array}{l}\text { September/ } \\
\text { October } 2005\end{array}$ & $\begin{array}{l}\text { October } \\
1998\end{array}$ \\
\hline Bh1 & Borehole & 3.0 & & & & & $S$ & \\
\hline $\mathrm{Bh} 2$ & Borehole & 3.0 & & & & & $S$ & \\
\hline $\mathrm{Bh} 3$ & Borehole & 3.0 & & & & & $\mathrm{~S}$ & \\
\hline Ow1 & Open well & 1.0 & 2.00 & & & $x, 0$ & & \\
\hline Ow2 & Open well & 15.0 & 1.70 & & & & $x, 0$ & \\
\hline $\mathrm{P} 1$ & Piezometer & 22.2 & 0.06 & 1 & $x, 0$ & $x, 0$ & $x, 0$ & \\
\hline $\mathrm{P} 2$ & Piezometer & 39.0 & 0.06 & 1 & $x, 0$ & $x, 0$ & $x, 0$ & \\
\hline P3 & Piezometer & 25.0 & 0.06 & 1 & $x, 0$ & $x, 0$ & $x, 0$ & \\
\hline P4 & piezometer & 21.6 & 0.10 & 1 & $x, 0$ & & $x, 0$ & \\
\hline P5 & Piezometer & 164.1 & 0.06 & 1 & $x, 0$ & & $x, 0$ & \\
\hline P6 & Piezometer & 87.0 & 0.06 & 1 & $x, 0$ & & $x, 0$ & \\
\hline P7 & Piezometer & 10.6 & 0.06 & 1 & & $x, 0$ & $x, 0$ & \\
\hline P8 & Piezometer & 13.4 & 0.06 & 1 & & $x, 0$ & $x, 0$ & \\
\hline P9 & Piezometer & 18.0 & 0.00 & 1 & & $x, 0$ & & \\
\hline P10 & Piezometer & 103.7 & 0.06 & 1 & $x, 0$ & & $x, 0$ & \\
\hline P11 & Piezometer & 8.5 & 0.06 & 1 & & $x, 0$ & $x, 0$ & \\
\hline P12 & Piezometer & 43.8 & 0.14 & 1 & & & $x, 0$ & \\
\hline P13 & Piezometer & 45.5 & 0.10 & 1 & & & $x, 0$ & \\
\hline Psm1 & Shallow piezometer & 4.0 & 0.05 & 1 & & & $x, 0$ & \\
\hline Psm2 & Shallow piezometer & 3.0 & 0.05 & 1 & & & $x, 0$ & \\
\hline Psm3 & Shallow piezometer & 5.0 & 0.05 & 1 & & & $x, 0$ & \\
\hline Psm4 & Shallow piezometer & 3.0 & 0.05 & 1 & & & $x, 0$ & \\
\hline Psm5 & Shallow piezometer & 4.0 & 0.05 & 1 & & & $x, 0$ & \\
\hline Sw1 & Laguna & & & & $x, 0$ & & & \\
\hline Sw2 & Santillán creek & & & & $x, 0$ & & & \\
\hline Sw6 & Laguna (close to P9) & & & & & & & $x$ \\
\hline
\end{tabular}

Variables $X$ and $O$ stand for ion and isotope analyses, respectively. All piezometers are installed with filter screens along the entire profile. Abbreviations P, Psm, Ow, Bh, and Sw stand for piezometer, shallow piezometer, open well, borehole and surface-water, respectively.

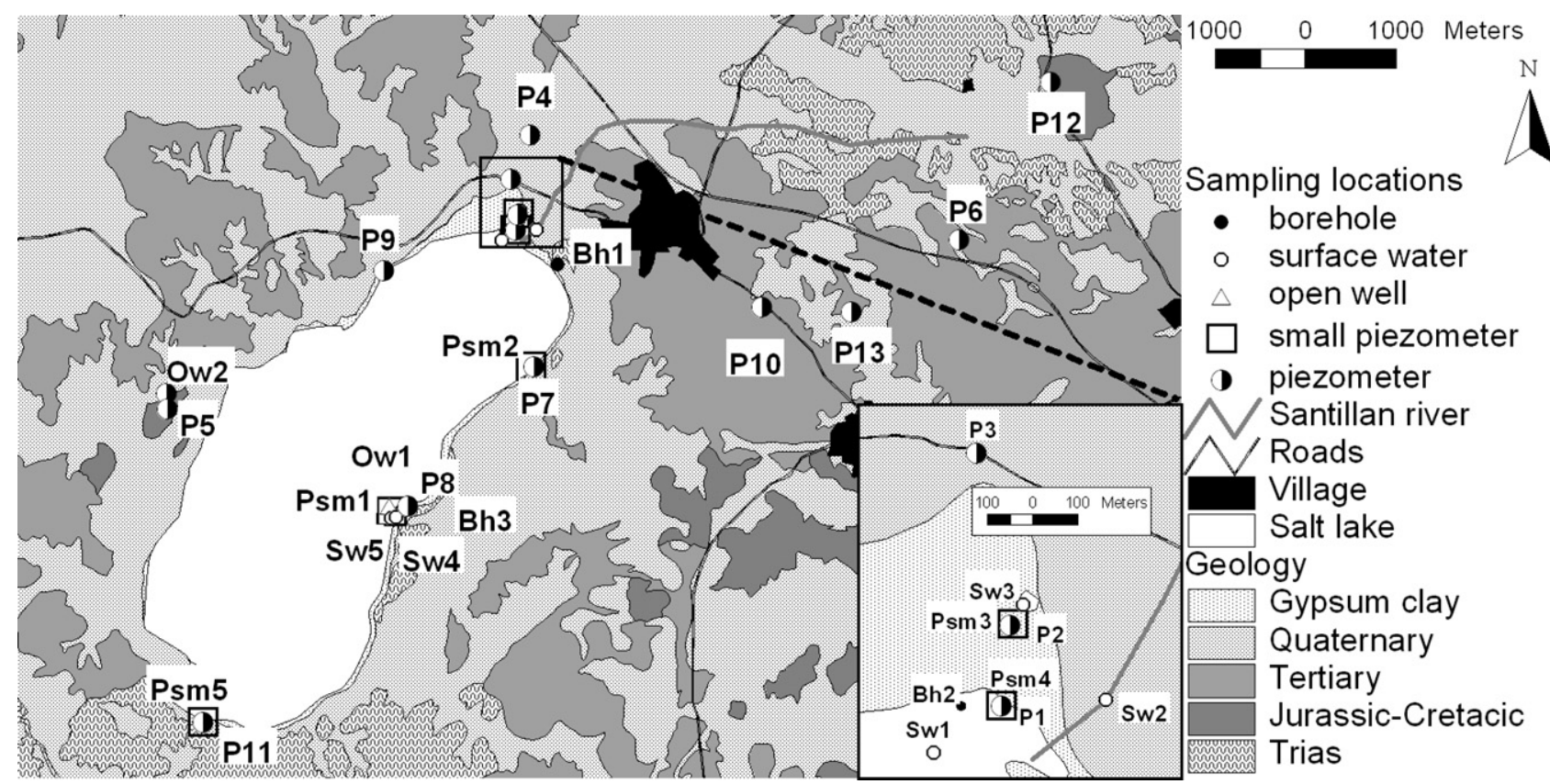

Figure 3 Location map and sampling sites. Geology was simplified after ITGE (1998). For labels of sampling sites refer to Table 1. 
as well as chemical precipitates such as carbonates and gypsum constitute the dominant mineral phases. The bottom of this clayey material was only found at the southern edge of the lake at $3 \mathrm{~m}$ below surface, whereas the northern and eastern edge of the Fuente de Piedra Salt lake show lacustrine clays with a minimum thickness of at least 5$7 \mathrm{~m}$. Thus, the thickness of these sediments is not evenly distributed and decreases considerably towards the south.

\section{Water levels and vertical hydraulic gradients}

The general trend of horizontal ground-water flow from the outer recharge areas towards the salt lake has already been investigated by Linares (1990). To examine vertical fluxes the hydraulic heads were determined at four locations where shallow piezometers have been installed adjacent to preexisting observation points of greater depths. These locations are situated at the northern edge (Psm3, Psm4), at the eastern edge (Psm1, Psm2) and at the southern edge of the salt lake (Psm5, Table 1, Fig. 3).

To determine freshwater heads the water density was determined according to McCain (1991)

$$
\begin{aligned}
\rho_{\mathrm{s}}= & \left(62.368+0.438603 \times 10^{-4} \mathrm{~S}+1.6007410\right. \\
& \left.\times 10^{-3}\left(10^{-4} S\right)^{2} \times C\right)
\end{aligned}
$$

where $\rho_{\mathrm{s}}$ is water density at standard conditions for temperature and pressure in $\mathrm{kg} / \mathrm{m}^{3}, C$ is the conversion factor $10^{-3} \times 16.01846$ from lb/cubic ft to $\mathrm{kg} / \mathrm{L}$. $S$ is TDS in $\mathrm{mg} / \mathrm{L}$ and was derived from EC by: TDS $(\mathrm{mg} / \mathrm{L})=0.7 \mathrm{EC}(\mu \mathrm{s} / \mathrm{cm})$.

EC is averaged conductivity along a vertical piezometer profile derived from conductivity logs which were performed with a vertical resolution of $0.2-0.5 \mathrm{~m}$.

According to Lussczynski (1961) vertical fluxes cannot be calculated by freshwater heads and have to corrected using the environmental-water head which he defined as follows:

$\rho_{\mathrm{f}} H_{\text {in }}=\rho_{\mathrm{f}} H_{\text {if }}-\left(\rho_{\mathrm{f}}-\rho_{\mathrm{a}}\right)\left(Z_{i}-Z_{r}\right)$

where $i=$ point in ground-water of variable density at the piezometer bottom, $H_{\text {in }}=$ environmental-water head at $i$ (masl), $H_{\text {if }}=$ freshwater head at $i$ (masl), $Z_{r}=$ top of the saturated zone $\left(\right.$ masl), $Z_{i}=$ elevation of $i$ (masl), $\rho_{\mathrm{f}}=$ freshwater density $(\mathrm{kg} / \mathrm{L}), \rho_{\mathrm{a}}=$ average density of water $(\mathrm{kg} / \mathrm{L})$ between $Z_{r}$ and $i$.
The freshwater head $H_{\text {if }}$ was calculated according to

$H_{\text {if }}=\frac{\rho_{\mathrm{a}}}{\rho_{\mathrm{f}}} \Psi+Z_{i}$

with $\psi=$ water gauge pressure in terms of the height above the piezometer bottom $(\mathrm{m}),\left(\psi+Z_{i}\right)$ corresponds to the hydraulic head measured in the field.

The calculated environmental-water heads in Fig. 4 indicate upward gradients at all four locations indicating upward directed flow at the edge of the salt lake. Because the piezometers are screened almost along their entire depth except the uppermost $2-3 \mathrm{~m}$, the calculated environmental heads are derived from measured hydraulic heads representing a mixed hydraulic potential. Therefore the application of environmental head, which requires short screens at discrete depths, is restricted in terms of the quantification of vertical fluxes. Nonetheless, this does not affect the general trend of vertical gradients determined with this method indicating ascending ground-water at the lake edge probably associated with free convection of ground-water below the salt lake as discussed later.

Temperature logs carried out at deeper boreholes which are located at a greater distance from the laguna (P6, P10 and $\mathrm{P} 13$ ) yielded thermal gradients of $2-2.5 \mathrm{C} / 100 \mathrm{~m}$. These values differ insignificantly from the average geothermal gradient of $3 \mathrm{C} / 100 \mathrm{~m}$. Hence, vertical ground-water flow in these boreholes is only of minor importance.

\section{Hydrogeochemistry of ground-water}

The analysed compositions of ground- and surface-water are compiled in Table 2. Three main types of ground-water can be distinguished in our study area. The first group comprises highly mineralised water of the sodium chloride type with elevated magnesium concentrations (Fig. 5). This type of ground-water was sampled mostly in piezometers close to the edge of the lake with the exception of Psm5 and P11 which are located at the southern lake edge and belong to group 2. Samples of group 1 yielded a high mineralisation up to $208 \mathrm{~g} / \mathrm{L}$ and are represented by black stiff diagrams in Fig. 6. Its composition is characteristic for saline environments and can be clearly related to processes of strong evaporation. Calculations of saturation indices are documented in Fig. 7 and yield oversaturation for gypsum and carbonate

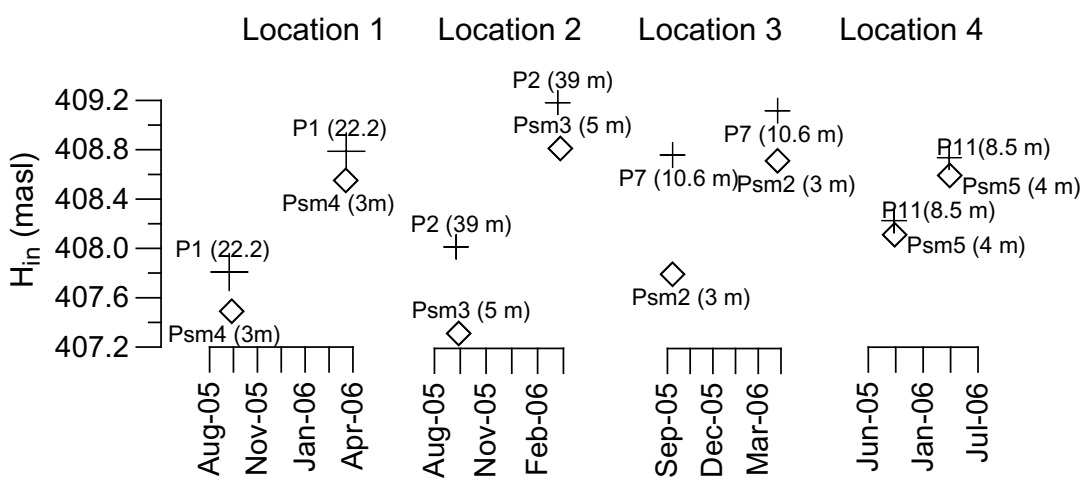

Figure 4 Calculated environmental-water heads $\left(H_{\text {in }}\right)$ at four different locations. Rhombic symbols represent shallow and cross symbols stand for deep piezometers. Numbers in brackets indicate the depth below surface. For piezometer labels see Fig. 3 and Table 1. 
Table 2 Chemical and stable isotope composition of sampled water

\begin{tabular}{|c|c|c|c|c|c|c|c|c|c|c|c|c|}
\hline ID & Sampling date & $\mathrm{pH}$ & Electric conductivity & $\mathrm{Na}$ & $\mathrm{K}$ & $\mathrm{Ca}$ & $\mathrm{Mg}$ & $\mathrm{Cl}$ & $\mathrm{SO}_{4}$ & $\mathrm{HCO}_{3}$ & 180 & $2 \mathrm{H}$ \\
\hline P1 & $2 / 4 / 2004$ & & 133,200 & 1461.5 & 1.6 & 85.8 & 370.3 & 1731.9 & 135.4 & & -1.71 & -16.9 \\
\hline P1 & $9 / 18 / 2005$ & 6.28 & 204,000 & 2979.6 & 3.1 & 97.3 & 674.8 & 3525.8 & 118.8 & 3.2 & & \\
\hline P1 & $2 / 22 / 2005$ & & 205,000 & 2801.2 & 3.5 & 81.8 & 724.1 & 3294.5 & 142.7 & & & \\
\hline P10 & $10 / 3 / 2005$ & 7.12 & 1312 & 4.1 & 0.1 & 6.1 & 2.4 & 6.5 & 1.2 & 5.1 & -5.89 & -40.3 \\
\hline P10 & $2 / 4 / 2004$ & & 990 & 7.0 & 0.3 & 0.2 & 0.3 & 6.3 & 1.1 & & -5.44 & -38.7 \\
\hline P11 & $9 / 20 / 2005$ & 7.33 & 7700 & 42.4 & 0.3 & 34.9 & 21.4 & 46.5 & 52.1 & 6.4 & -5.51 & -40.2 \\
\hline P11 & $2 / 22 / 2005$ & & 8120 & 41.7 & 0.2 & 33.9 & 18.9 & 46.5 & 44.8 & & & \\
\hline P12 & $10 / 3 / 2005$ & 7.26 & 654 & 0.8 & 0.0 & 3.7 & 2.6 & 1.1 & 1.1 & 4.6 & -6.18 & -39.9 \\
\hline P13 & $10 / 3 / 2005$ & 7.11 & 1815 & 5.7 & 0.0 & 11.0 & 1.4 & 8.2 & 5.7 & 2.9 & -5.35 & -37.8 \\
\hline P2 & $2 / 22 / 2005$ & & 201,000 & 2792.5 & 4.3 & 104.3 & 699.4 & 3816.4 & 145.8 & & & \\
\hline P2 & $2 / 4 / 2004$ & & 114,200 & 1191.8 & 1.8 & 49.9 & 279.8 & 1461.1 & 81.3 & & -2.41 & -20.3 \\
\hline P2 & $2 / 22 / 2005$ & & 46,800 & 383.6 & 8.3 & 19.5 & 76.5 & 450.2 & 33.3 & & & \\
\hline P3 & $9 / 22 / 2005$ & 6.54 & 107,400 & 1109.2 & 1.4 & 57.4 & 279.8 & 1551.4 & 62.5 & 6.2 & -2.49 & -22.6 \\
\hline P3 & $2 / 4 / 2004$ & & 168,100 & 1992.2 & 2.7 & 89.8 & 493.7 & 2569.6 & 114.6 & & -0.33 & -9.3 \\
\hline P3 & $2 / 22 / 2005$ & & 26,700 & 166.2 & 0.3 & 34.4 & 79.8 & 266.6 & 20.8 & & & \\
\hline P3 & $2 / 22 / 2005$ & & 168,300 & 1905.2 & 2.7 & 94.8 & 502.0 & 2428.6 & 105.0 & & & \\
\hline P3 & $2 / 4 / 2004$ & & 15,600 & 113.1 & 0.3 & 17.0 & 37.9 & 148.4 & 12.5 & & -5.01 & -34.3 \\
\hline P4 & $2 / 4 / 2004$ & & 19,500 & 91.3 & 0.3 & 44.9 & 70.8 & 215.8 & 9.4 & & -5.09 & -34.7 \\
\hline P4 & $9 / 22 / 2005$ & 6.82 & 6170 & 20.0 & 0.1 & 21.5 & 24.7 & 52.2 & 10.8 & 6.0 & -5.22 & -37.7 \\
\hline P5 & $9 / 18 / 2005$ & 6.70 & 130,300 & 1413.7 & 1.9 & 97.3 & 288.0 & 1847.5 & 83.8 & & -5.96 & -44.3 \\
\hline P5 & $2 / 4 / 2004$ & & 0 & 587.2 & 0.5 & 37.9 & 114.4 & 702.3 & 31.3 & & -3.94 & -28.2 \\
\hline P6 & $2 / 4 / 2004$ & & 200,000 & 139.2 & 1.2 & 74.9 & 78.2 & 243.4 & 52.1 & & -6.04 & -43.6 \\
\hline P6 & $9 / 21 / 2005$ & 6.88 & 10,520 & 36.3 & 0.5 & 59.9 & 20.6 & 84.6 & 30.2 & 2.0 & -2.31 & -22.2 \\
\hline P7 & $9 / 16 / 2005$ & 6.52 & 166,900 & 1913.9 & 3.7 & 54.9 & 584.2 & 2482.2 & 145.8 & 5.0 & -0.75 & -13.2 \\
\hline P7 & $2 / 22 / 2005$ & & 187,000 & 2187.9 & 4.3 & 56.9 & 691.2 & 2820.7 & 171.9 & & & \\
\hline P7 & $2 / 22 / 2005$ & & 137,000 & 1396.3 & 2.6 & 43.9 & 427.9 & 1664.2 & 122.9 & & & \\
\hline P8 & $2 / 22 / 2005$ & & 31,200 & 250.1 & 0.5 & 15.0 & 54.3 & 295.6 & 23.3 & & & \\
\hline P9 & $2 / 22 / 2005$ & & 166,000 & 2040.0 & 1.6 & 239.5 & 510.2 & 2795.3 & 71.7 & & & \\
\hline P9 & $2 / 22 / 2005$ & & 166,000 & 1700.8 & 1.6 & 194.6 & 419.7 & 2279.1 & 71.3 & & & \\
\hline Psm1 & $9 / 15 / 2005$ & & 190,800 & 2522.9 & 6.4 & 60.9 & 757.0 & 3525.8 & 218.8 & 2.2 & 2.06 & 4.5 \\
\hline Psm2 & $9 / 16 / 2005$ & 7.10 & 186,900 & 2435.9 & 5.6 & 74.9 & 625.4 & 3384.8 & 208.3 & 4.9 & 0.3 & -6.5 \\
\hline Psm3 & $9 / 17 / 2005$ & 7.05 & 94,200 & 765.6 & 2.0 & 67.4 & 255.1 & 1063.4 & 114.6 & 4.5 & 1.28 & -5.8 \\
\hline Psm4 & $9 / 19 / 2005$ & 6.90 & 123,800 & 1087.4 & 1.7 & 104.8 & 378.5 & 1762.9 & 125.0 & 4.3 & -2.07 & -20.9 \\
\hline Psm5 & $9 / 20 / 2005$ & 7.30 & 9620 & 55.7 & 0.3 & 31.9 & 24.7 & 56.4 & 62.5 & 7.1 & -5.49 & -40.2 \\
\hline Sw1 & $2 / 4 / 2004$ & & 54,200 & 578 & 2.17 & 64.8 & 146.4 & 699 & 83.3 & & -3.01 & -22.1 \\
\hline Sw2 & $2 / 4 / 2004$ & & 5900 & 31.54 & 0.2 & 15.97 & 16.46 & 47.25 & 13.24 & & -5.19 & -35.9 \\
\hline Sw6 & $10 / 27 / 1998$ & 8.04 & 67,000 & 576.16 & 2.17 & 64.71 & 172.66 & 742.81 & 91.93 & 2.7 & & \\
\hline
\end{tabular}

Electric conductivity is given in $\mu \mathrm{s} / \mathrm{cm}$, concentration of major ions is given meq/L and stable isotopes of water are presented in $\delta$-values. The station name refers to Fig. 3.

minerals for samples taken at shallow piezometers installed within the lake sediments at the lake edge (Psm1, Psm2, Psm3, Psm4) as well as for deeper boreholes at the northern lake edge ( $\mathrm{P} 1$ and $\mathrm{P} 2$ ). These samples show a comparatively high proportion of $\mathrm{Ca}$ and $\mathrm{Mg}$ indicating intensive water-rock interaction due to long residence times. This is also in agreement with results of Heredia et al. (2004) who found tritium ages of more than 50 years for ground-water sampled in the lake sediments. The other piezometers located in the vicinity of the lake are oversaturated in dolomite and/or calcite.

The second group contains samples located in the Miocene basin at a greater distance to the lake and close to the southern lake edge (P4, Psm5, P6, P10, P11, P13). Group 2 is characterised by a mineralisation below $6 \mathrm{~g} / \mathrm{L}$. Samples taken close to the lake (P4, P11, Psm5) show elevated proportions of $\mathrm{Ca}, \mathrm{Mg}$, and sulphate, whereas the other samples of group 2 show only elevated proportions of $\mathrm{Ca}$ and sul- phate, which are probably derived from Triassic evaporites. Calculations of saturation indices resulted in saturation of calcite in all samples. Undersaturation in dolomite and elevated sulphate concentrations indicate dedolomitisation due to gypsum dissolution. Many samples of group 2 (Psm5, P11 and P6) are at saturation with gypsum. A strong fingerprint of Triassic evaporites can be observed at P6 which yields a comparatively high mineralisation of $6 \mathrm{~g} / \mathrm{L}$. P6 is oversaturated in calcite and undersaturated in dolomite also pointing to dedolomitisation.

The less mineralised type (group 3) is represented by only one sample from the spring of the Santillán creek (P12) which discharges Jurassic carbonates and is of the $\mathrm{Ca}$ $\mathrm{HCO}_{3}$-type with a mineralisation of about $0.5 \mathrm{~g} / \mathrm{L}$. Group 3 can be considered as the original regional ground-water composition which constitutes an important discharge source of the entire basin. 

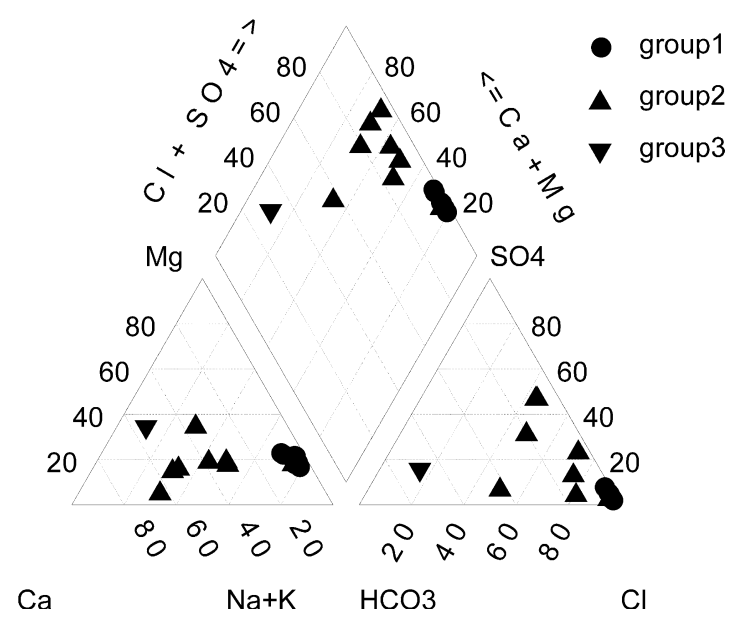

Figure 5 Piper plot of ground-water samples from September/October 2005.

The general zonation of ground-water types and the hydrogeochemical varieties at the lake are reflected also by the mineralisation. Mineralisation of ground-water around the lake shows a great variety, ranging from extremely mineralised samples of $206 \mathrm{~g} / \mathrm{L}$ at the northern edge (Psm1) to
$6 \mathrm{~g} / \mathrm{L}$ at the southern edge of the lake (P11). Intermediate values between the northern and southern edges were analysed at the eastern edge of the lake at P7 and P8. This leads to the conclusion that the southern lake edge is less subjected to evaporation and receives a major amount of meteoric freshwater which is supported by the isotope data as discussed below. Furthermore the northern lake edge is discharged by more mineralised ground-water that has been in contact with Triassic evaporites.

Salinities of surface-water sampled in February 2004 ranged from $220 \mathrm{~g} / \mathrm{L}$ to $3.6 \mathrm{~g} / \mathrm{L}$ which lies within the range of salinities measured in previous studies mentioned above and reflects different degrees of evaporation.

In Fig. 8 a scatter plot of Ca versus sulphate shows mainly ratios around 1 indicating a dominant influence of gypsum dissolution of ground-water in the Miocene basin (group 2). Higher mineralised samples (Psm1, Psm2, P7, P9) show deviations from this ratio. The reduced ratios found in Psm1, Psm2, P7 are due to relative enrichment of magnesium which is presumably due to the dissolution of minerals bearing magnesium and sulphate. The elevated $\mathrm{Ca} /$ sulphate ratio at P9 may be related to the chemical divide concept. Evaporation of an initial solution with a $\mathrm{Ca}$ /sulphate ratio higher than 1 may increase this ratio considerably. Beside evaporation there are many other effects such as ion

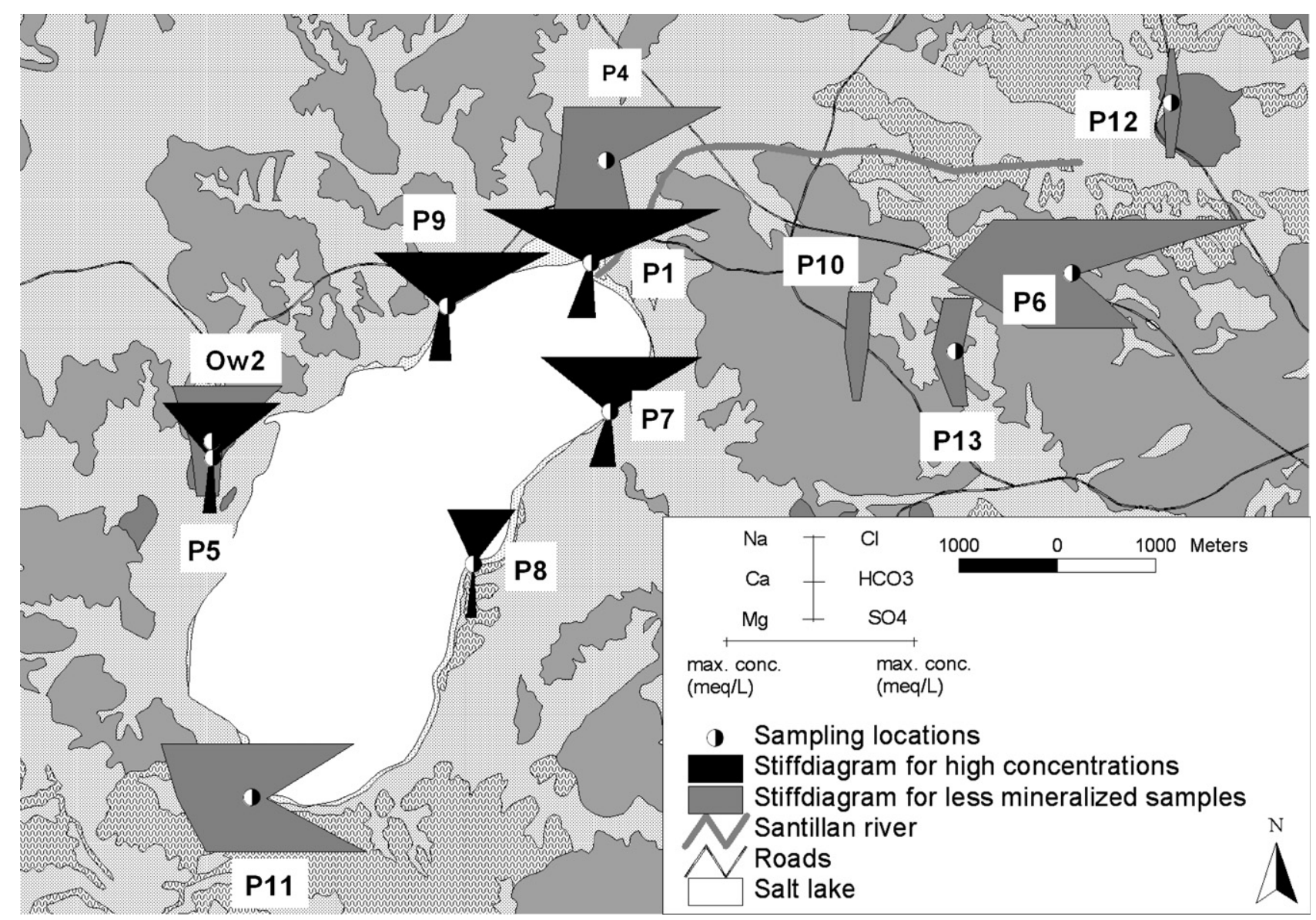

Figure 6 Stiffmap plot of analysed hydrogeochemical data of ground-water sampled in September/October 2005. Note that black stiff diagrams represent highly saline samples scaled for maximum concentrations of $6000 \mathrm{meq} / \mathrm{L}$. Grey stiff diagrams are plotted for low concentrated ground-water scaled for $50 \mathrm{meq} / \mathrm{L}$ as maximum concentration. For geologic units refer to Fig. 3 . 


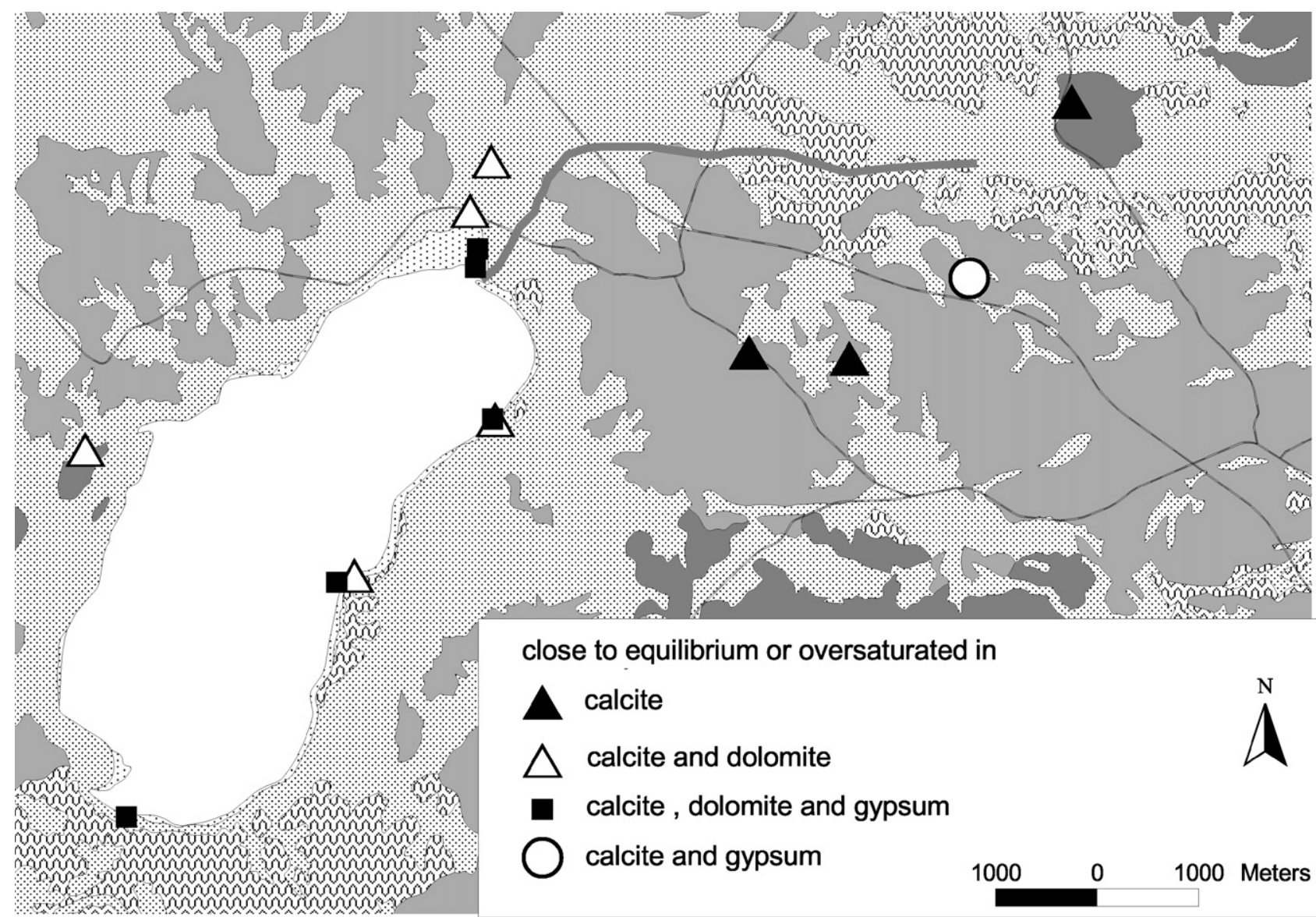

Figure 7 Saturation indices with regard to gypsum for analysed samples taken in September/October 2005. For geology and other explanations refer to Fig. 3. Calculations of saturation indices for samples with ionic strength below 0.3 were performed with PHREEQC-2 (version 2.8) and the PHREEQC-database. Samples with a higher ionic strength were calculated using the Pitzer database.

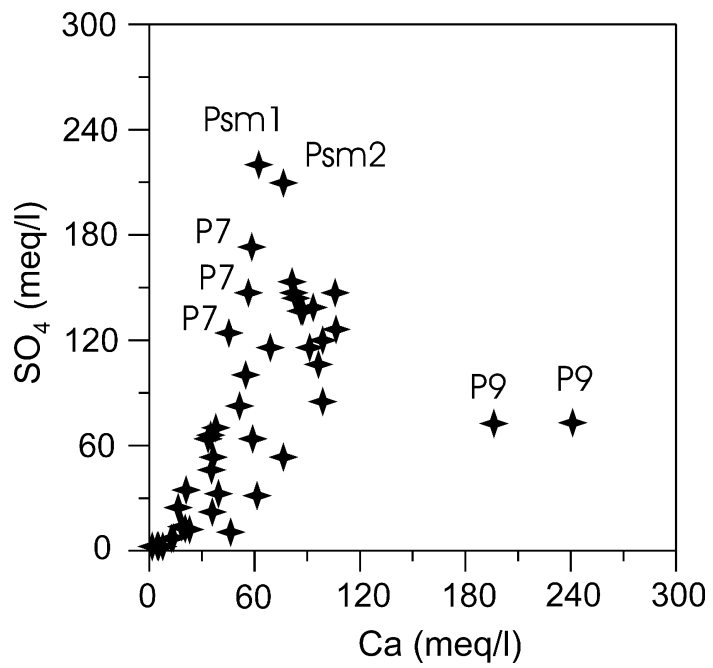

Figure 8 Scatter plot of Ca versus sulphate of ground-water samples from February 2004 and September 2005. For labelled symbols refer to Fig. 3.

exchange or dissolution of evaporates which could affect the $\mathrm{Ca}$ /sulphate ratio. Dissolution of $\mathrm{Ca}$ - and $\mathrm{Cl}$-bearing salts such as tachyhydrite $\left(\mathrm{CaMg}_{2} \mathrm{Cl}_{6} \cdot 12\left(\mathrm{H}_{2} \mathrm{O}\right)\right)$ is unlikely because this mineral phase is a rare constituent of marine salt deposits and was not detected by Rodríguez Jiménez et al. (1993).

The $\mathrm{Cl} / \mathrm{Br}$ ratio is suitable for identifying different sources of ground-water salinisation. For sea water the ratio is around $300(\mathrm{Cl}-\mathrm{SMOW}=19400 \mathrm{mg} / \mathrm{kg}$; Br-SMOW = $67 \mathrm{mg} /$ $\mathrm{kg})$, which has been constant for all oceans since the Permian (Thomas, 1994) and can be taken as reference value. Surface-water and ground-water that have been subjected to evaporation show similar ratios. Since bromide is less compatible in precipitating salts, it enriches to a greater extent than chloride during evaporation processes in the residual brines leading to ratios below 300 . Precipitated salts are depleted in bromide, which causes chloride/bromide ratios for leaching water above 3000 (Mazor, 1997). The chloride versus bromide diagram (Fig. 9) yields more or less constant $\mathrm{Cl} / \mathrm{Br}$ coefficients for nearly all analysed samples within a range from 400 to 800 , which is slightly above the ratios found in seawater. The fingerprint of evaporation leading to ground-water enriched in bromide can be detected up to a distance of about $1.1 \mathrm{~km}$ to the northern lake edge, which is documented by $\mathrm{Cl} / \mathrm{Br}$ ratios of 370 at $\mathrm{P} 4$. This leads to the conclusion that highly mineralised evaporated brines infiltrate into the aquifer. As long as the brines are undersaturated in halite they may dissolve halite of the lacustrine 


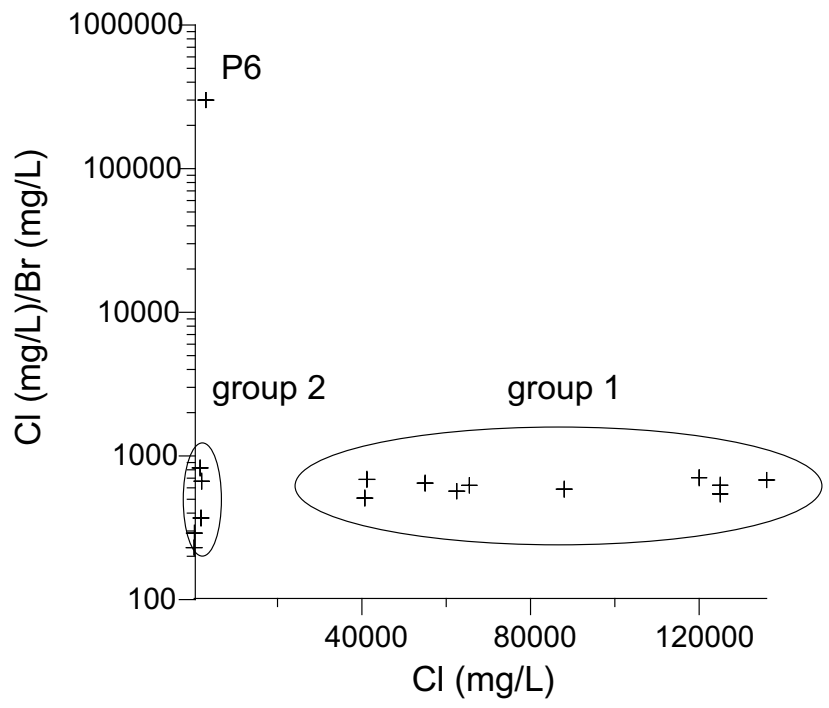

Figure 9 Scatter plot of $\mathrm{Cl} / \mathrm{Br}$ ratios versus $\mathrm{Cl}$ concentrations of analysed samples with mineralisations higher than $1 \mathrm{~g} / \mathrm{L}$. Group 1 represents highly mineralised ground-water samples taken directly in lake sediments or at the northern edge of the salt lake. Group 2 includes samples from the less mineralised southern edge of the lake as well as samples taken at piezometers a few hundred meters away from the northern lake edge.

evaporites leading to $\mathrm{Cl} / \mathrm{Br}$ ratios higher than ratios normally found in evaporated surface-water or seawater. Note that even elevated amounts of dissolved halite would not considerably increase the initial $\mathrm{Cl} / \mathrm{Br}$ ratio of the brine which has been subjected to evaporation. If $50 \%$ of the total chloride and bromide of the ground-water originated from halite dissolution, the resulting $\mathrm{Cl} / \mathrm{Br}$ ratio would increase from an initial value of 300 to around 600 assuming an initial $\mathrm{Cl} / \mathrm{Br}$ ratio of 3000 for the dissolving evaporite. A further reason for these slightly elevated ratios may be a reduced degree of evaporation or mixing with freshwater that has not been subjected to evaporation.

In contrast to these results, P6, which is located at a greater distance to the lake, shows extremely high $\mathrm{Cl} / \mathrm{Br}$ ratios indicating that the elevated mineralisation is due to the dissolution of Triassic evaporites. We conclude from this observation that these Triassic evaporites may constitute an important source of the lacustrine evaporites.

\section{Fresh-saline water interface}

To obtain information about the vertical change of groundwater composition conductivity logs were carried out in September/October 2005 and April 2006 at piezometers that are located along a line vertical to the northern shoreline of the laguna (P1, P2, P3 and P4) (Fig. 10).

These conductivity logs showed that mineralisation of ground-water rose with depth in all piezometers before reaching more or less constant values at a certain depth. These different levels of mineralisation indicate at least two different sources of ground-water. Less mineralisation in the upper part is presumably due to meteoric groundwater recharged by infiltrating rainwater. The lower part

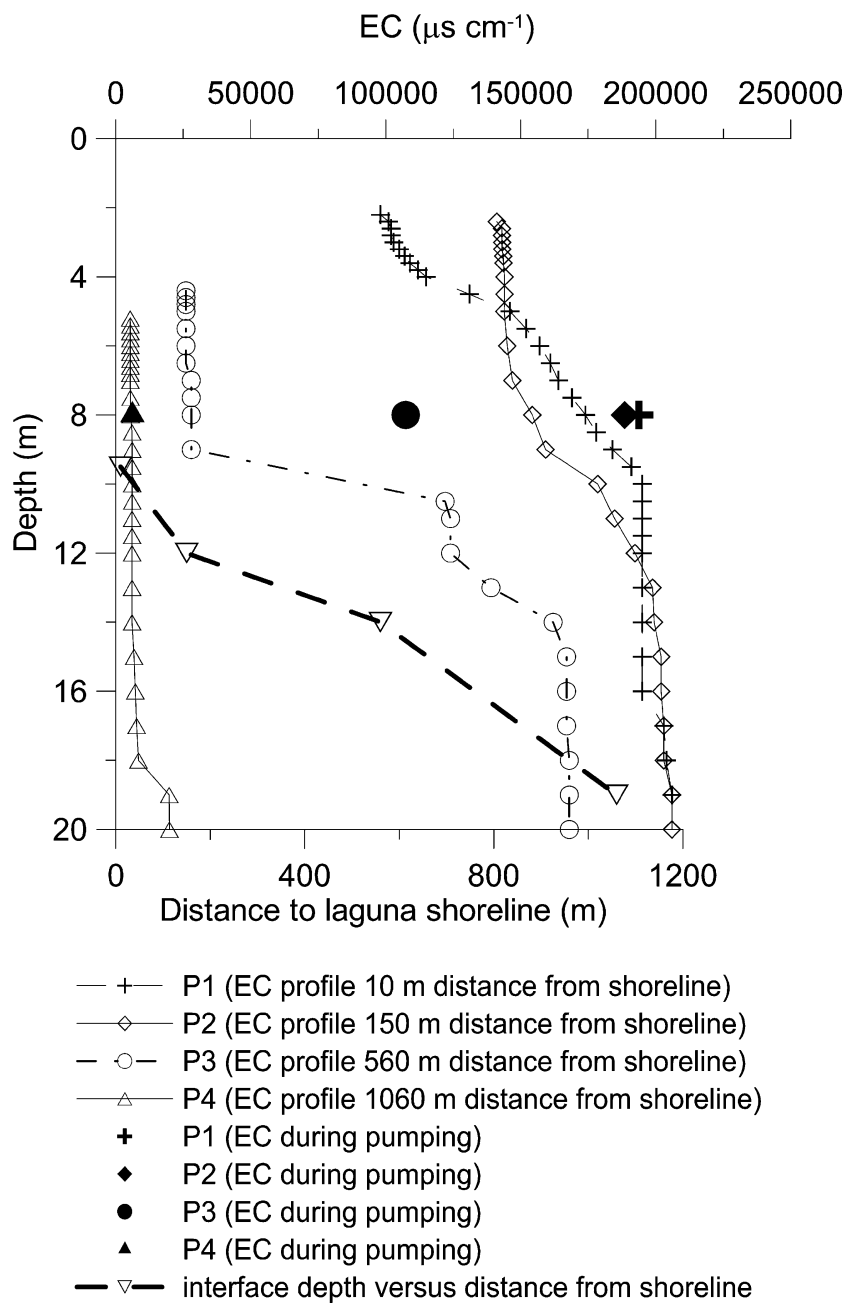

Figure 10 Conductivity logs carried out at the northern transect (P1, P2, P3 and P4) in September/October 2005 before pumping. The dashed line indicates the descending interface with rising distance to the laguna. Black shaded point symbols represent time constant electroconductivities during pumping.

shows a higher mineralisation possibly due to evaporation and/or dissolution of evaporites.

Comparing the conductivity logs along the section P1 to P4 yields a decreasing mineralisation with rising distance to the laguna. Furthermore it becomes obvious that the interface between highly saline ground-water and less mineralised water descends with increasing distance from the lake edge. As discussed below the isotope data indicate clearly that the saline ground-water originates from evaporated surface-water brines of the lake. Halite precipitation is assumed to be restricted to the dry season but this could not be verified by our samples which were all undersaturated in halite.

The contact plane between two water bodies of contrasting water density can also be approximated by the GhybenHerzberg equation (Herzberg, 1901):

$H_{\mathrm{s}}=\left(\rho_{\mathrm{f}} /\left(\rho_{\mathrm{s}}-\rho_{\mathrm{f}}\right)\right) H_{\mathrm{f}}$

where $H_{\mathrm{s}}$ is the depth of the interface, $H_{\mathrm{f}}$ is the elevation of the water-table, $\rho_{\mathrm{f}}$ is the density of freshwater and $\rho_{\mathrm{s}}$ is the density of salt water. 
Though this equation was based on observations of the interface of ground-water and seawater in coastal areas, it can also be applied to saline lakes. With $H_{\mathrm{f}}$ of $0.45 \mathrm{~m}$ measured at P4, an interface depth of around $17 \mathrm{~m}$ below the hydraulic head of the ground-water in the lake would correspond to a relation $H_{\mathrm{s}}=34 \times H_{\mathrm{f}}$. This is slightly shallower than interface depths of $H_{\mathrm{s}}=40 \times H_{\mathrm{f}}$ found in coastal areas. Nonetheless, much shallower interface depths have been observed in other salt lake environments such as the Dead Sea with $H_{\mathrm{s}}=4.35 \times H_{\mathrm{f}}$ (Yechieli and Wood, 2002). However, the Ghyben-Herzberg equation is a very simple approach and the density distribution could be calculated more concisely by a numerical model considering variable densities. Because this study focuses on hydrogeochemical and isotope data as well as on geochemical modelling, the presentation of a numerical flow and transport model is not within the scope of this article.

The fresh-saline water interface descends $4.5 \mathrm{~m}$ over a distance of around $550 \mathrm{~m}$ from P1 to P3 which corresponds to a gradient of $0.8 \%$. This is also supported by the interface top detected at P4 which shows a decrease of $8 \mathrm{~m}$ over a distance of $1060 \mathrm{~m}$ from P1 to P4.

Comparing temporal changes of conductivities between September/October 2005 and April 2006 yields a significant rise in the interface of $3-4 \mathrm{~m}$ in piezometers $\mathrm{P} 1$ and $\mathrm{P7}$, which are located at a distance of only a few meters away from the lake edge (Fig. 11). In April 2006 the laguna was partly replenished during the wet season, laterally expanding its hydrogeochemical fingerprint. Nonetheless, this effect could only be observed at a few meters distance from the shoreline. The other piezometers show only a minor difference between September/October 2005 and April 2006. This seasonality is therefore limited to the proximate shoreline of the lake.

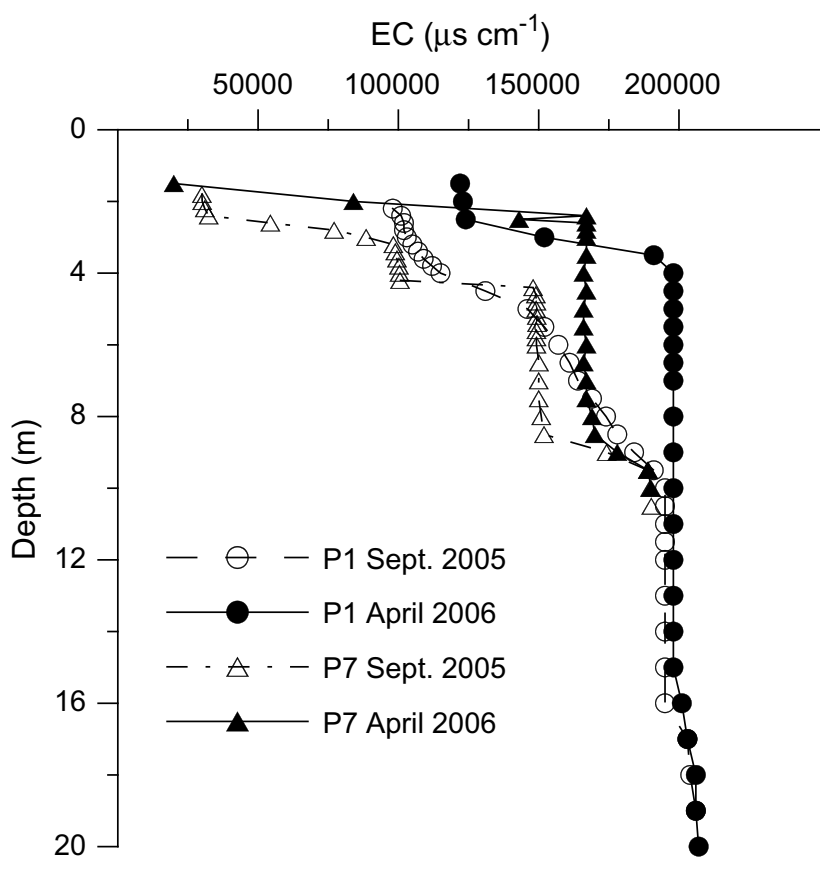

Figure 11 Conductivity logs without pumping after the dry season (September 2005) and after the wet season (April 2006) at P1 and P7.

\section{Dominating ground-water discharge regimes at the} northern lake edge

To characterise the mineralisation of ground-water in areas with elevated permeabilities the electric conductivity logs performed in September/October 2005 at the northern transect were carried out before and after pumping. Pumping continued until constant values of temperature and conductivity were obtained. These time constant values of electroconductivities during pumping reflect the mineralisation of the dominating ground-water flow in zones of higher permeabilities. The measured constant electroconductivities show that highly mineralised ground-water constitutes the dominate discharge at P1 and P2 which are located in the direct vicinity of the lake (Fig. 10). At P3 and P4, a few hundred meters away from the lake edge low-mineralised subsurface flow recharged by infiltrating rain water is clearly of higher importance. Because elevated permeabilities for low-mineralised subsurface flow could not be detected close to the lake shore, a reduced lateral extension of permeable sediments at shallow depths has to be assumed. This point to a restricted subsurface flow of low-mineralised groundwater originated from infiltrating rainwater towards the lake and may enhance surface discharge of meteoric water into the lake or lead to mixing processes with mineralised ground-water in the subsurface. As discussed above, variable density modelling could be useful for future predictions of ground-water salt concentrations.

\section{Lateral hydrogeochemical changes between surface-water and- ground-water}

The hydrogeochemical changes at the interface between the laguna and the ground-water were investigated along a section located at the northern border of the laguna, which is zoomed out in Fig. 3. Because the lake and the Santillán creek were dry during the main sampling campaign in September/October 2005 surface-water samples of February 2004 are considered here. The Schoeller diagram (Fig. 12) yields similar hydrogeochemical patterns of surface-water and ground-water taken in piezometers close to the shoreline (P1/Psm4, P2/Psm3, P3). This indicates the absence or minor importance of geochemical reactions along the pathway between ground-water and the laguna. The multilevel piezometers (P1/Psm4) and ( $\mathrm{P} 2 / \mathrm{Psm} 3)$ yield rising concentrations with depth and rising proportions of sodium chloride which were also supported by conductivity logs discussed later. P4 is located at a greater distance from the shore line $(1.1 \mathrm{~km})$ and shows a minor influence of saline waters proceeding from the laguna. The Santillán creek (Sw2) which constitutes the main discharge of the Fuente de Piedra basin shows a similar composition to ground-water sampled at P4 except that its ground-water is enriched in magnesium and depleted in sodium.

\section{Stable isotopes}

The analysed samples from September 2005 and February 2004 are plotting all along an evaporation line with an approximate slope of 5.5 (Fig. 13). The isotope composition 


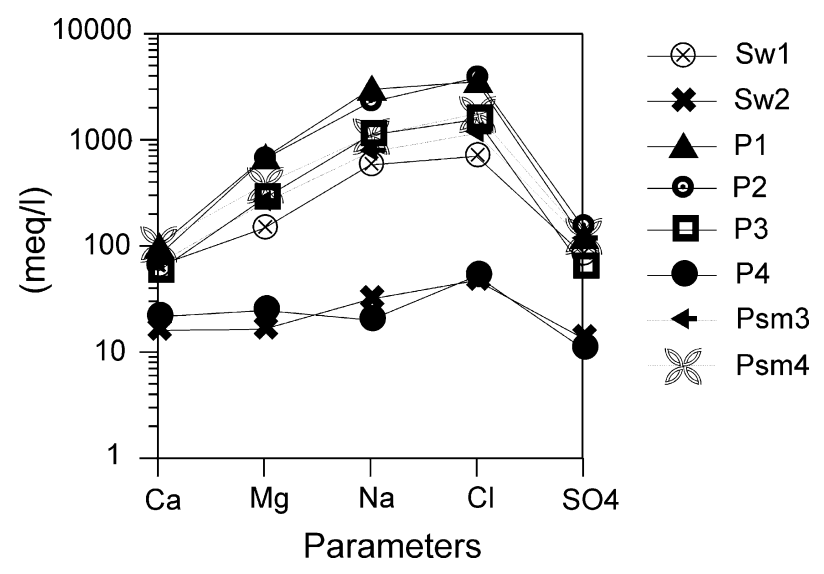

Figure 12 Schoeller diagram of analysed water samples along a transect at the northern lake edge. Ground-water samples were taken in September 2005. The surface-water samples of the laguna (Sw1) and of the Santillán creek (Sw2) were taken in February 2004.

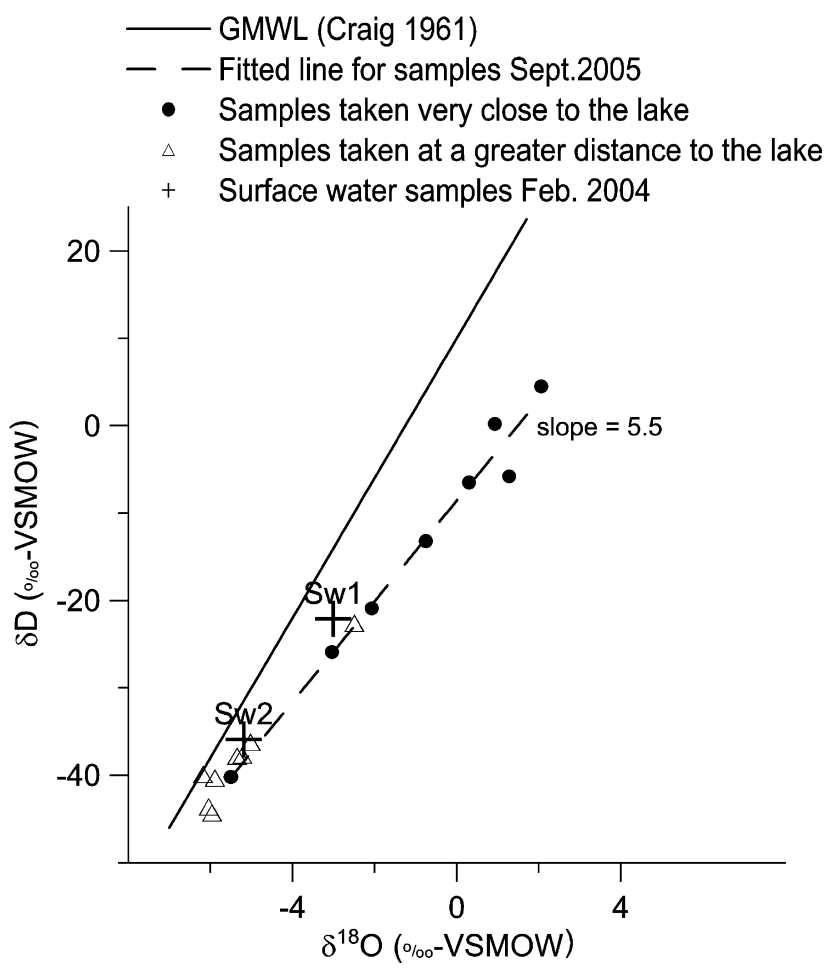

Figure $13 \delta \mathrm{D}$ versus $\delta^{18} \mathrm{O}$ plot for samples taken in September 2005. Since no surface-water was available, two samples of Santillán River (SW2) and laguna (SW1) taken in February 2004 are plotted.

of water taken from piezometers close to the lake ranges from strong isotope enrichment at the northern lake edge to lower levels towards the southern lake edge pointing to a decreasing degree of evaporation from north to south. In view of the reduced thickness of clay sediments at this location this is assumed to be due to mixing with regional ground-water.
Data from piezometers located several hundred meters from the lake plot in a cluster of points at the lower left of Fig. 13, these being slightly enriched in $D$ and ${ }^{18} O$ relative to regional ground-water derived from the interception scheme, except for one analysis that shows a moderate enrichment. This sample was taken at P3 at a distance of more than $500 \mathrm{~m}$ from the northern lake edge and is clearly influenced by lake water.

Lake water sampled in February 2004 (SW1) shows moderate enrichment of heavy isotopes due to evaporation. Data of Santillán river (SW2) show a similar insignificant enrichment to that of data taken at a greater distance from the lake.

\section{Hydrogeochemical modelling of brine evolution}

To investigate the hydrogeochemical evolution and interrelation of different brines in our study site several scenarios were calculated with PHREEQC-2 (version 2.13.2) using the PITZER database (Table 3 ). All scenarios are calculated in equilibrium with $\mathrm{CO}_{2}$ gas.

To investigate the hydrogeochemical evolution of the surface-water during different stages of evaporation two forward modelling scenarios were performed. The first scenario considers evaporation of Arroyo Santillán water and mineral precipitation whereas the second scenario also includes equilibrium with the present mineral phases in the subsurface during evaporation.

In the first scenario (scenario 1) the evaporation of sample SW2 of Arroyo Santillán (Table 2) was simulated starting from the assumption that this tributary discharges into the Fuente de Piedra Salt lake and is subjected to evaporation (Fig. 14). Precipitation of the minerals (calcite, gypsum, anhydrite; polyhalite, hexahydrite, halite; bischofite) analysed by Rodríguez Jiménez et al. (1993) was allowed and no mineral dissolution was considered. The simulations yield precipitation of gypsum after $80 \%$ of evaporation whereas calcite and dolomite remain undersaturated. Calcite starts to precipitate after $90 \%$ of evaporation when dolomite also becomes oversaturated. Fig. 14 indicates that more than $90 \%$ evaporation of Arroyo Santillán water in combination with mineral precipitation account for the composition of most of the elements analysed in the salt lake (SW1) except Mg. The surplus of $\mathrm{Mg}$ in the simulated solution may be explained by precipitation of $\mathrm{Mg}$-bearing minerals such as sepiolite which has been observed in similar environments subjected to evaporation by Buck et al. (2006).

The second forward scenario (scenario 2) corresponds to scenario 1 but additionally includes dissolution of minerals. The initial solution subjected to evaporation is again SW2 (Arroyo Santillán) and mineral phases for equilibrium reactions were defined according to the dominant mineral assemblage analysed for lacustrine sediments of the Fuente de Piedra salt lake by Rodríguez Jiménez et al. (1993) without allowing for dolomite precipitation during the simulation. The simulation yields dissolution of dolomite and gypsum and precipitation of calcite up to a degree of $50 \%$ evaporation. This process is called dedolomitisation and normally occurs as a consequence of elevated concentrations of calcium in the liquid phase due to gypsum 
Table 3 Scenarios calculated with PHREEQC-2

\begin{tabular}{|c|c|c|}
\hline & Process & Precipitating phases \\
\hline Scenario 1 & $\begin{array}{l}\text { Evaporation of Arroyo } \\
\text { Santillán }\end{array}$ & $\begin{array}{l}\text { Calcite, gypsum, anhydrite; } \\
\text { polyhalite, hexahydrite, } \\
\text { halite; bischofite; } \mathrm{CO}_{2}(\mathrm{~g})\end{array}$ \\
\hline Scenario 2 & As scenario 1 & Calcite, dolomite, gypsum \\
\hline Scenario 3 & 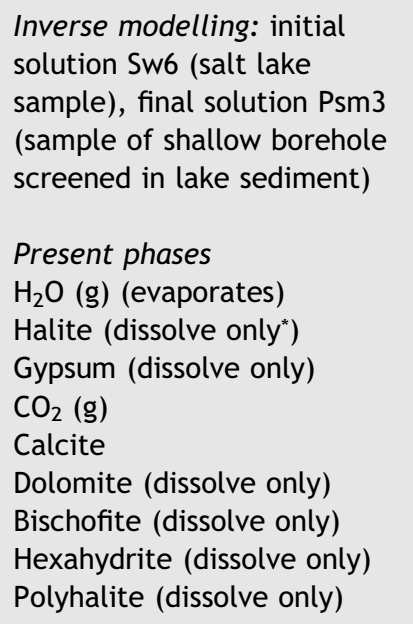 & $\begin{array}{l}\text { Phase mole transfers (moles) with minimal phases calculated by } \\
\text { PHREEQC-2: } \\
\mathrm{H}_{2} \mathrm{O}(\mathrm{g})-6.922 \mathrm{e}+00 \mathrm{H}_{2} \mathrm{O} \\
\mathrm{Halite} 3.004 \mathrm{e}-01 \mathrm{NaCl} \\
\text { Gypsum } 11.664 \mathrm{e}-02 \mathrm{CaSO}_{4}: 2 \mathrm{H}_{2} \mathrm{O} \\
\mathrm{CO}_{2}(\mathrm{~g}) 1.501 \mathrm{e}-03 \mathrm{CO}_{2} \\
\mathrm{Calcite}-2.504 \mathrm{e}-02 \mathrm{CaCO}_{3} \\
\text { Dolomite } 1.3 \mathrm{e}-02 \mathrm{CaMg}_{3}\left(\mathrm{CO}_{3}\right)_{2} \\
\text { Bischofite } 4.027 \mathrm{e}-02 \mathrm{MgCl}_{2}: 6 \mathrm{H}_{2} \mathrm{O}\end{array}$ \\
\hline Scenario 4 & 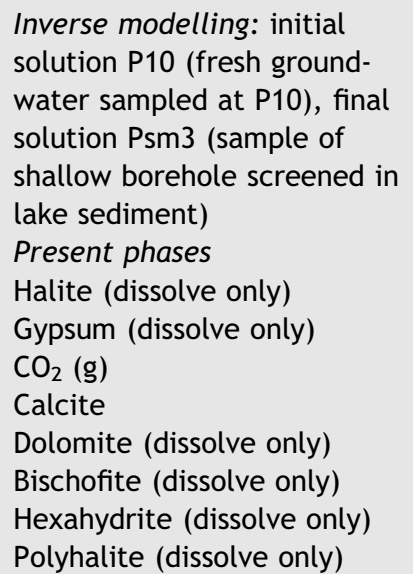 & No thermodynamically feasible solution \\
\hline
\end{tabular}

All scenarios were calculated with equilibrium to atmospheric $\mathrm{CO}_{2}(\mathrm{~g})$ with a log partial pressure of -3.5 . Positive numbers of phase mole transfer indicate dissolution and negative numbers precipitation of minerals. Precipitation of dolomite was not allowed in all simulations. 'Dissolve only' means that the respective mineral is not allowed to precipitate.

dissolution. Between $50 \%$ and $80 \%$ of evaporation dolomite becomes oversaturated but is not allowed to precipitate whereas calcite and gypsum are still dissolving. A simulated equilibrium of mineral phases with a brine of more than $80 \%$ degree of evaporation results in dissolution of calcite, and precipitation of gypsum leading to decreasing sulphate concentrations. The simulated water compositions of $90 \%$ evaporation plotted in Fig. 15 fits in well with the analysed ground-water sample Psm3. Therefore, the possibility that the ground-water brine has evolved by evaporation of surface-water in equilibrium with the analysed mineral assemblage of the lacustrine sediment was verified by these hydrochemical simulations. The simulated lack of dolomite precipitation is in accordance with sediment analysis of Rodríguez Jiménez et al. (1993) where no dolomite was analysed in the uppermost $0.3 \mathrm{~m}$ below surface. Therefore the dolomite found below $0.3 \mathrm{~m}$ depth is assumed to be the result of posterior dolomitisation, a kinetically controlled process that has not been taken into account in our thermodynamic equilibrium calculations.

To describe the chemical evolution observed on two hypothetic hydrologic flow paths in terms of sets of balanced reactions two inverse models were set up (scenario 3 and scenario4). Scenario 3 refers to a hypothetic flow path where evaporated surface-water infiltrates into the subsurface and reacts with the present mineral phases. A second hypothetic flowpath from the peripheral part of the Fuente de Piedra basin towards its centre with the salt lake has been considered in a further inverse model (scenario 4).

The initial solution is a surface-water sample with alkalinity data (SW6) and the final solution is the analysed 


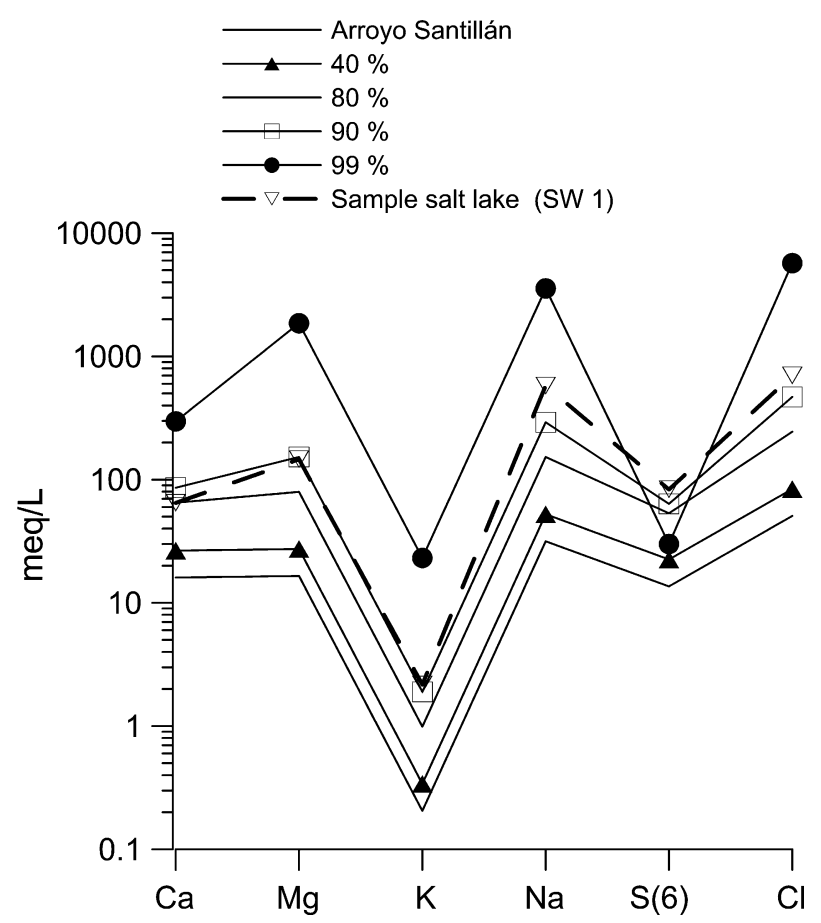

Figure 14 Measured salt lake composition (SW1) and simulated evaporation of analysed sample from Arroyo Santillán tributary (SW2). Both analysed samples were taken in February 2004 (Tables 1 and 2).

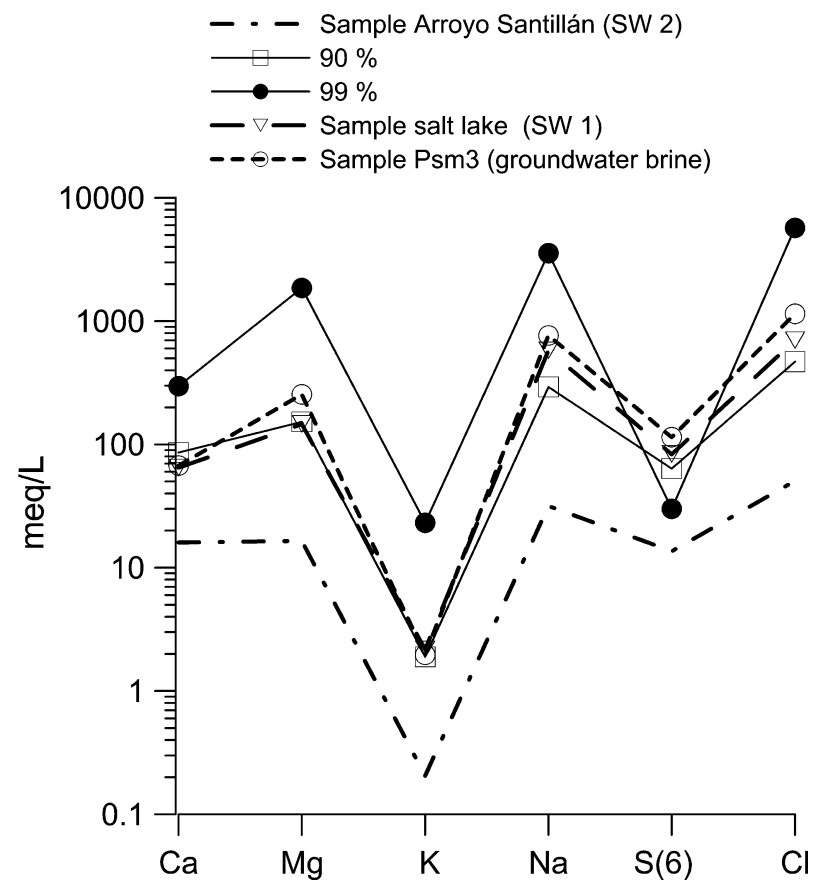

Figure 15 Simulated evaporation of tributary Arroyo Santillán with equilibrium to mineral phases. Precipitation of dolomite is not allowed during the simulations. Numbers in $\%$ indicate degree of simulated evaporation of Arroyo Santillán. Additionally analysed samples of salt lake (SW1) and groundwater brine (Psm3) are plotted. Sample IDs refer to Tables 1 and 2. brine sample Psm3. The possibility of evaporation and the precipitation or dissolution of 9 mineral phases analysed by Rodríguez Jiménez et al. (1993) is included. The inverse modelling found 8 possible solutions. Table 3 presents a thermodynamically feasible solution showing that 1.12 -fold concentration of the salt lake water and the dissolution of halite, dolomite, gypsum and bischofite in combination with the precipitated calcite are sufficient to reproduce all the differences between surface- (Sw6) and ground-water brine (Psm3). This concurs with the saturation indices of the salt lake solution, which is oversaturated in calcite and undersaturated in all dissolving mineral phases.

In scenario 4 the initial composition corresponds to a low-mineralised ground-water sample taken at the piezometer P10 at a greater distance from the lake (Fig. 3 and Table 2). The final composition represents the shallow groundwater brine analysed at Psm3. Again, the mineral phases for equilibrium reactions were defined according to analyses of lacustrine sediments of the Fuente de Piedra salt lake from Rodríguez Jiménez et al. (1993). Because the initial and the final ground-water compositions are undersaturated in all mineral phases except in calcite, only calcite was allowed to precipitate during the simulations. All other minerals are forced only to dissolve. In accordance with the scenarios defined above precipitation of dolomite was not allowed during the simulations. The inverse modelling did not find a solution able to explain the differences between the initial and final ground-water composition. Hence, further processes such as mixing, ion exchange, etc. should be considered to explain the hydrogeochemical evolution along this flowpath.

\section{Conceptual model}

Based on the individual results of this research a conceptual model was developed proposing the principal flow system and interaction of surface-water, brines and meteoric ground-water within this basin along a cross-section orientated from north to south (Fig. 16). Meteoric ground-water flow both from the south and from the north is orientated towards the lake. Convection cells have developed below the lake whose asymmetry is due to the reduced thickness of Quaternary and Miocene sediments towards the southern lake edge. Mixing takes place at the interface of these convection cells with the freshwater discharge and leads to recycled brines that are carried back up towards the lake by the fresher flow system. The existence of Triassic evaporites was identified by elevated mineralisations and a high $\mathrm{CL} / \mathrm{Br}$ ratio at $\mathrm{P} 6$. The dissolution of these evaporites may constitute an important source of solutes and contribute to an elevated thickness of lacustrine evaporites at the northern lake edge. Nonetheless, the thickness of the lake sediments which are constituted not only by chemical precipitates but also by fine grained silts and clays delivered by the adjacent source rocks of the watershed is also probably related to an elevated subsidence of the basin towards the north. This is supported by basin sediment mapping which indicates that the former lake extended $3 \mathrm{~km}$ northward as mentioned before in the description of the study area. 

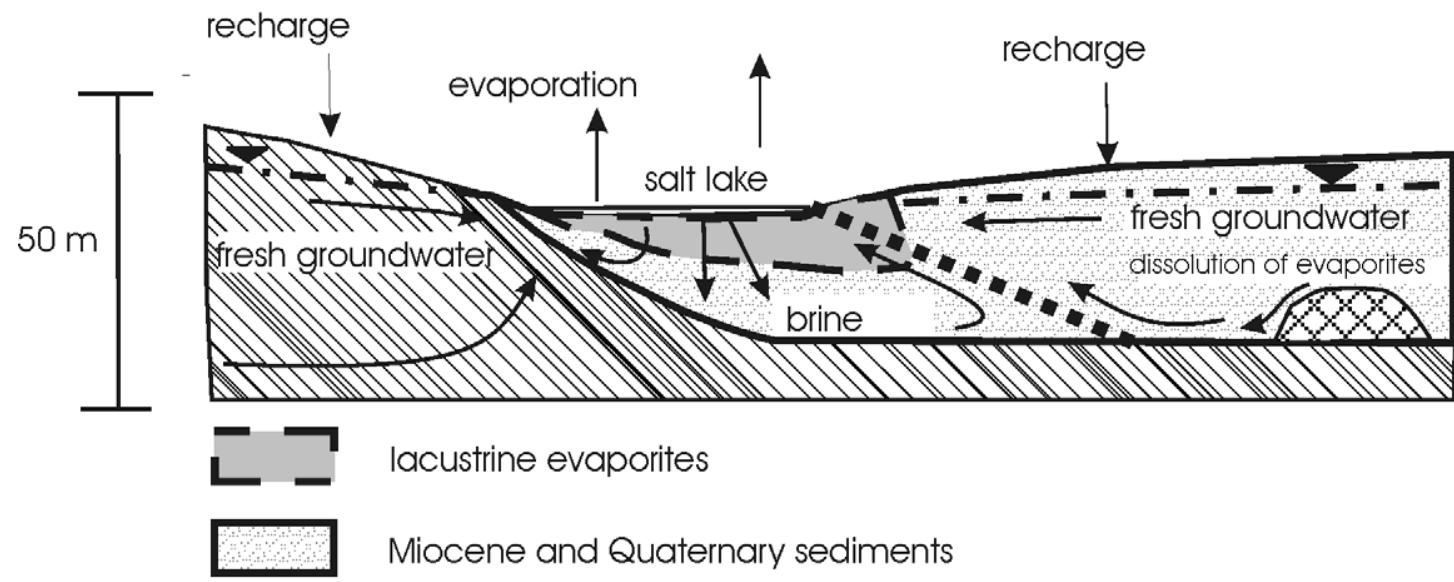

\title{
\$४ Triassic evaporites
}

\author{
DIVIII) Triassic basement
}

Figure 16 Principal sketch illustrating the flow system along a cross-section.

\section{Conclusions}

The hydrogeochemical composition of water sampled in the Fuente de Piedra basin ranges from the CaHCO3-type represented by the tributary spring of Arroyo Santillán through Miocene ground-water types with slightly elevated concentrations of chloride and sulphate to highly concentrated brines in the direct vicinity of the lake edge. Saturation indices in the Miocene basin indicated elevated sulphate concentrations, oversaturation in calcite and undersaturation in dolomite pointing to dedolomitisation due to gypsum dissolution. The brine composition in the direct vicinity of the lake shows oversaturation in calcite, dolomite and partly in gypsum and a decreasing mineralisation from north to south maintaining a similar major ion composition. This is associated with a decreasing thickness of lacustrine evaporites from more than $20 \mathrm{~m}$ in the north to less than $3 \mathrm{~m}$ in the south. Isotope data point to a higher degree of surfacewater evaporation in the northern lake edge whereas the southern area seems to receive a higher amount of meteoric freshwater.

Beside the lacustrine evaporites a further source of salinisation was identified by $\mathrm{Cl} / \mathrm{Br}$ ratios and isotope data of the ground-water. Mineralised ground-water without isotope enrichment and very high $\mathrm{Cl} / \mathrm{Br}$ ratios at one piezometer in the Miocene basin located north-east of the salt lake indicated dissolution of Triassic evaporites. Continuous dissolution of these Triassic evaporites, subsequent transport and precipitation beneath the lake may enhance sedimentation rates at the northern part of the lake. Nonetheless, tectonic subsidence in the central part of the basin is assumed to be the governing process for evaporite sedimentation.

The calculation of environmental-water heads at four different observation points located at the northern, eastern and southern lake edges yields upward gradients.
The salinity interface and the evaporative fingerprint of stable isotopes, in combination with hydraulic upward fluxes described above, indicate the existence of convection cells below the lake. Tritium ages of more than 50 years detected by Heredia et al. (2004) in ground-water sampled in lake sediments point to the existence of recycled brines at the lake edge.

Conductivity logs carried out along a profile perpendicular to the northern lake edge yielded a restricted subsurface discharge of meteoric freshwater towards the lake owing to the limited lateral extension of permeable sediment layers.

Hydrogeochemical modelling of the different brines support the indication of dedolomitisation within the lacustrine sediments obtained by ground-water analyses. The simulated exclusion of dolomite precipitation concurred with analysed surface and ground-water samples. Analysed dolomite minerals below $0.3 \mathrm{~m}$ depth are supposed to be formed by posterior dolomitisation. Inverse modelling results indicate that the lacustrine brine composition would have evolved from evaporated lake water in equilibrium with the mineral assemblage of the lake sediments. By contrast, the formation of the lacustrine brine composition cannot be explained only by interaction of the same mineral assemblage with ground-water of the Miocene basin and further processes such as mixing, ion exchange, etc. have to be considered.

\section{Acknowledgments}

This study was conducted within the cooperation between Freie Universität Berlin, Alfred Wegener Institute Potsdam, Universidad de Granada and Instituto Geológico Minero de España (IGME). The authors thank IGME for financial support of this research. Furthermore we gratefully thank the 
personal and authorities of the Fuente de Piedra Natural Reserve for support and for providing all necessary facilities for our field work.

\section{References}

Aketwana, E.A., Richardson, D.S., 2004. Geochemical and isotopic evidence of a ground-water source in the Corral Canyon meadow complex, central Nevada, USA. Hydrological Processes 18 (15), 2801-2815.

Almécija, C., 1997. Estudio hidrológico de los enclaves lagunares del norte de la provincia de Málaga, Granada, 518 pp.

Bourg, C., Stievenard, M., Jouzel, J., 2001. Hydrogen and oxygen isotopic composition of aqueous salt solutions by gas-water equilibration method. Chemical Geology 173, 331-337.

Buck, B., Wolff, K., Merkler, D., MacMillan, N., 2006. Salt mineralogy of Las Vegas Wash, Nevada: morphology and subsurface evaporation. Soil Science Society of America Journal 70 (5), 1639-1651.

Clark, I., Fritz, P., 1999. Environmental Isotopes in Hydrogeology. Lewis Publishers, NY.

Craig, H., Gordon, L., 1965. Deuterium and oxygen-18 variations in the ocean and the marine atmosphere. In: Tongiorgi, E. (Ed.), Conference on Stable Isotopes in Oceanographic Studies and Paleotemperatures. Spoleto, Italy, pp. 9-130.

Cruz-SanJulián, J., 1974. Estudio geológico del sector Cañete La Real - Teba - Osuna (cordillera bética, región occidental), Granada, $431 \mathrm{pp}$

Duffy, C.J., Al-Hassan, S., 1988. Ground-water circulation in closed desert basins: topographic scaling and climatic forcing. Water Resources Research 24 (10), 1675-1688.

Fan, Y., Duffy, C.J., Oliver, D.S., 1997. Density-driven groundwater flow in closed desert basins: field investigations and numerical experiments. Journal of Hydrology 196, 139-184.

Fenk, C., Menz, C., 2007. Interaction between salt lake and groundwater - a hydrogeochemical, isotopegeochemical and sedimentological study of the Fuente de Piedra Basin, Spain. Master Thesis, Freie Universität Berlin, Berlin, 260 pp.

Gonfiantini, R., 1986. Environmental isotopes in lake studies. In: Fritz, P., Fontes, J. (Eds.), Handbook of Environmental Isotope Geochemistry. Elsevier, pp. 113-206.

Hardie, L.A., Eugster, H.P., 1970. The evolution of closed basin brines. Mineralogical Society of America, Special Paper 3, 273290.

Hardie, L.A., Smoot, J.P., Eugster, H.P., 1978. Saline lakes and their deposits: a sedimentological approach. In: Matter, A., Tucker, M.E. (Eds.), Modern and Ancient Lake Sediments. International Association of Sedimentologists, Special Publication, pp. 7-41.

Heredia Díaz, J., Araguás Araguás, L., Ruiz Hernández, J.M., 2004. Descripción de la dinámica subterránea en la cuenca de Fuente de Piedra (Malaga). Caracterización hidroquímica e isotópica. In: A.F. Uría (Ed.), VIII Simposio de Hidrogeología. Asociación Española de Hidrología Subterránea, Zaragoza, pp. 271-280.

Heredia, J., Araguás-Araguás, L., Ruiz, J.M., 2004. Delineation of ground-water dynamics and flow patterns under variable density conditions: case of the subsurface brine of Fuente de Piedra (SW Spain). In: Araguás-Araguás, L., Custodio, E., Manzano, M., (Eds.), 18th Saltwater Intrusion Meeting. Spanish Geological Survey, Cartagena, Spain, pp. 679-692.

Herzberg, B., 1901. Die wasserversorgung einiger nordseebäder. Journal für Gasbeleuchtung und Wasserversorgung 44, 815-819, 842-844.

Horita, J., Cole, D., Wesolowski, D., 1995. The activity-composition relationship of oxygen and hydrogen isotopes in aqueous salt solutions; III, Vapor-liquid water equilibration of $\mathrm{NaCl}$ solutions to $350^{\circ} \mathrm{C}$. Geochimica et Cosmochimica Acta 59, 1139-1151.
ITGE (Ed.), 1998. Hidrogeología de la Reserva Natural de la laguna de Fuente de Piedra (Málaga). ITGE, Madrid, 79 pp.

Johannsen, K., Oswald, S., Held, R., Kinzelbach, W., 2006. Numerical simulation of three-dimensional saltwater-freshwater fingering instabilities observed in a porous medium. Advances in Water Resources 29 (11), 1690-1704.

Linares, L., 1990. Hidrogeología de la laguna de Fuente de Piedra (Málaga), Granada, 343 pp.

Linares, L., Rendón, M., 1999. La laguna de Fuente de Piedra (Málaga), un área endorreica de interés ecológico ligada al karst yesífero-salino. In: Durán, J.J., López, J. (Eds.), Karst en Andalucía. ITGE, Madrid, pp. 165-172.

Liu, X.Q., Cai, K.Q., Yu, S.S., 2004. Geochemical simulation of the formation of brine and salt minerals based on Pitzer model in Caka salt lake. Science in China Series D-Earth Sciences 47 (8), 720-726.

Lussczynski, N.J., 1961. Head and flow of ground-water of variable density. Journal of Geophysical Research 66 (12), 4247-4256.

Mazor, E., 1997. Chemical and Isotopic Ground-water Hydrology. Dekker, NY, 413.

McCain, W.J., 1991. Reservoir fluid property correlations - state of the art. SPE Reservoir Engineering 6, 266-272.

Meyer, H., 2000. Isotope studies of hydrogen and oxygen in ground ice - experiences with the equilibration technique. Isotopes Environmental Health Studies 36, 133-149.

Moreira, J.M., Montes, C., 2005. Caracterización ambiental de humedales en Andalucía. Junta de Andalucía, Sevilla, 511 pp.

Narayan, K.A., Armstrong, D., 1995. Simulation of ground-water interception at lake Ranfurly, Victoria, incorporating variable density flow and solute transport. Journal of Hydrology 165, 161-184.

Parkhurst, D.L., Appelo, C.A.J., 1999. User's guide to Phreeqc (Version 2). A computer program for speciation, batch-reaction, one dimensional transport, and inverse geochemical calculations. Water-Resources Investigations Report 99-4259, US Geological Survey, Denver, Colorado.

Pitzer, K.S., 1987. Thermodynamic model for aqueous solutions of liquid density. In: Carmichael, Eugster (Eds.), Thermodynamic Modeling of Geological Materials. Minerals, Fluids and Melts, Reviews in Mineralogy. Mineralogical Society of America, pp. 97-142.

Rendón, M., 1996. La laguna de Fuente de Piedra en la dinámica de la población de flamencos del Mediterráneo Occidental, Malaga, $369 \mathrm{pp}$.

Rodríguez Jiménez, Carrasco, F., Benavente, J., Almécija, C., 1993. Mineralogía de los sedimentos de la Laguna de Fuente de Piedra (provincia de Malaga). Geogaceta 14, pp. 18-20.

Rodríguez-Rodríguez, M., 2002. Contribución hidrogeológica y limnológica a la caracterización ambiental de zonas húmedas de Andalucía oriental, Granada, 205 pp.

Rodríguez-Rodríguez, M., Benavente, J., Cruz-SanJulián, J., Moral, F., 2006a. Estimation of ground-water exchange with semi-arid playa lakes (Antequera region, southern Spain). Journal of Arid Environments 66 (2), 272-289.

Rodríguez-Rodríguez, M., Benavente, J., Moral, F., 2006b. High density ground-water flow, major-ion chemistry and field experiments in a closed basin: Fuente de Piedra Playa Lake (Spain). American Journal of Environmental Sciences 1, 164-171.

Rogers, D.B., Dreiss, S.J., 1995. Saline ground-water in Mono basin, California. Water Resources Research 31 (12), 3131-3150.

Rosen, M.R., 1994. The importance of ground-water in playas: a review of playa classifications and the sedimentology and hydrology of playas. Geological Society of America, Special Paper 289, 1-18.

Ruiz, J.M., Heredia, J., Araguas, L., Domingo, A.G., 2006. Contribución de la tomografía eléctrica en la caracterización del sistema hidrogeológico de la laguna de Fuente de Piedra. In: S.G.S. (IGME) (Ed.), Las aguas subterráneas en los países 
mediterráneos. Hidrogeología y aguas subterráneas, Madrid, pp. 353-357.

Simmons, C.T., Narayan, K.A., 1997. Mixed convection processes below a saline disposal basin. Journal of Hydrology 194, 263-285.

Simmons, C.T., Narayan, K.A., Wooding, R.A., 1999. On a test case for density-dependent ground-water flow and solute transport models: the salt lake problem. Water Resources Research 35, $3607-3620$.

Simmons, C.T., Narayan, K.A., Woods, J.A., Herczeg, A.L., 2002. Ground-water flow and solute transport at the Mourquong saline water disposal basin, Murray basin, southeastern Australia. Hydrogeology Journal 10, 278-295.

Thomas, L., 1994. Hydrogeochemische Untersuchungen an den Ölfeldwässern aus NW-Deutschland und dem Oberrheingraben und ihre Modellierung unter dem Aspekt der Entwicklung eines Expertensysthems für Fluid-Rock-Interactions (Diss.). Berliner Geowissenschaftliche Abhandlungen. Selbstverlag Fachbereich Geowissenschaften, Berlin.

Vallejos, A., Pulido-Bosch, A., Martin-Rosales, W., Calvache, M.L., 1997. Contribution of environmental isotopes to the understanding of complex hydrologic systems. A case study: Sierra de
Gador, SE Spain. Earth Surface Processes and Landforms 22 1157-1168.

Vera, J.A., 2004. Geología de España. Spanish Geological SocietySpanish Geological Survey, Madrid, 884 pp.

Wood, W.W., Sanford, W.E., 1990. Ground-water control on evaporite deposition. Economic Geology 85, 1226-1235.

Wooding, R.A., Tyler, S.W., White, I., 1997a. Convection in groundwater below an evaporating salt lake: 1 . Onset of instability. Water Resources Research 33 (6), 1199-1217.

Wooding, R.A., Tyler, S.W., White, I., Anderson, P.A., 1997b. Convection in ground-water below an evaporating salt lake. 2. Evolution of fingers and plumes. Water Resources Research 33, 1219-1228.

Yechieli, Y., Wood, W.W., 2002. Hydrogeologic processes in saline systems: playas, sabkhas, and saline lakes. Earth-Science Reviews 58, 343-365.

Zimmermann, U., 1979. Determination by stable isotopes of underground inflow and outflow and evaporation of young artificial ground-water lakes. In: Mortimer, C. (Ed.), Application of Nuclear Techniques to the Study of Lake Dynamics. IAEA, Vienna, Austria, pp. 87-94. 